\title{
Exergy Analysis of Solid Fuel-Fired Heat and Power Plants: A Review
}

\author{
Francis Chinweuba Eboh ${ }^{1,2, *}$, Peter Ahlström ${ }^{1}$ and Tobias Richards ${ }^{1}$ \\ 1 Swedish Centre for Resource Recovery, University of Borås, 50190 Borås, Sweden; \\ peter.ahlstrom@hb.se (P.A.); tobias.richards@hb.se (T.R.) \\ 2 Department of Mechanical Engineering, Michael Okpara University of Agriculture, \\ Umudike P.M.B 7267, Abia State, Nigeria \\ * Correspondence: eboh.francis_chinweuba@hb.se; Tel.: +46-33-435-5903; Fax: +46-33-435-4008 \\ Academic Editor: Xidong Wang \\ Received: 16 November 2016; Accepted: 19 January 2017; Published: 1 February 2017
}

\begin{abstract}
The growing demand for energy is particularly important to engineers with respect to how the energy produced by heat and power plants can be used efficiently. Formerly, performance evaluation of thermal power plants was done through energy analysis. However, the energy method does not account for irreversibilities within the system. An effective method to measure and improve efficiency of thermal power plant is exergy analysis. Exergy analysis is used to evaluate the performance of a system and its main advantage is enhancement of the energy conversion process. It helps identify the main points of exergy destruction, the quantity and causes of this destruction, as well as show which areas in the system and components have potential for improvements. The current study is a comprehensive review of exergy analyses applied in the solid fuels heat and power sector, which includes coal, biomass and a combination of these feedstocks as fuels. The methods for the evaluation of the exergy efficiency and the exergy destruction are surveyed in each part of the plant. The current review is expected to advance understanding of exergy analysis and its usefulness in the energy and power sectors: it will assist in the performance assessment, analysis, optimization and cost effectiveness of the design of heat and power plant systems in these sectors.
\end{abstract}

Keywords: exergy; heat and power; solid fuels; system efficiencies

\section{Introduction}

The worldwide demand for, and consumption of energy and power are expected to increase in future years due to the expansion of urbanization, the rapid rate of industrialization and the continuous improvements being made to the standard of living [1,2]. Humankind currently uses $410 \times 10^{18}$ joules per annum, which is equal to the energy content of over 90,000 billion litres of oil, i.e., commercially-traded energy [3]. Nevertheless, the rate of consumption is constrained by the available resources $[4,5]$ and a consequence of energy sources being limited is that their efficient use requires thermal processes to be optimized, with special emphasis being placed on the energy associated with exhaust gases and other forms of waste heat [6]. The energy sector needs not only to be effective in order to meet the increasing demands for heat and electricity from society, but also to utilize the resources that are available for their production by improving the efficiency of plants.

Normally, performance assessment of a system is carried out using the concept of the first law of thermodynamics, which is based on the conservation of energy [1,7]. However, using energy alone in the efficiency analysis of processes is bound to lead to misconceptions, misevaluations and poor decisions [8]: it only embraces information of the inputs and outputs of the energy in the process and excludes its quality [9]. The use of second law analysis allows the quality of the energy to be 
determined, and the irreversibilities quantified, as a result of the entropy that is generated and which causes inefficiency in the process [1]. Second law analysis is often based on the concept of "exergy", also known as "available energy", "availability" or "useful energy" [8]. This enables the main sources of loss to be identified and provides directions for improving performance within the system [7].

Exergy is the maximum amount of work that can be obtained from a stream of matter, heat or work as it is brought into equilibrium with the environment [10]. The reference environment of temperature, pressure and mixture of substances found in abundance in nature must be defined: it is given a zero exergy (i.e., "dead state") [11]. Exergy analysis has been widely used in the evaluation, simulation and design of thermo-chemical and thermo-mechanical systems [12]. Its application reaches beyond technical analysis, as it is also used in thermo-economic, environmental and sustainability analyses of industrial systems [13]: exergy analysis allows for the thermodynamic assessment of energy conservation because it provides the tool for making a clear distinction between the energy lost to the environment and internal irreversibilities in the process [6]. It also represents quantitatively the useful energy, i.e., the work content of the great variety of streams (comprising mass, heat, work), that enters into the system and accounts for the exergy destroyed during a process, which is proportional to the entropy generated [14]. This destruction of exergy, or irreversibility, is a yardstick by which losses in the plant are determined and compared [7].

The energy in solid fuels can be converted into useful products through biological/biochemical and thermochemical processes $[15,16]$. In terms of faster reaction rate and reduction in larger amount and volume of solid materials, the thermochemical processes are more efficient than the biological methods [17]. The three main thermochemical conversion methods are combustion, pyrolysis and gasification [18]. The combustion process is a commercially viable option [19] and the most widely used method for solid fuels conversion into heat and power [15,20].

In the literature, only a few papers have taken a comprehensive view of exergy analysis on the biomass-based fuels and coal-fired heat and power plant. Saidur et al. [21] reviewed the application of exergy analysis to different biomass fuels. Their investigations were based on biomass gasification rather than conversion through combustion processes. Kaushik et al. [18] examined energy and exergy analysis of coal-fired thermal power plants. Though their studies were based on thermochemical conversion of the fuel using a combustion method, they only examined the design conditions of existing plants. To the best knowledge of the authors, there is no review of exergy analysis of biomass and coal co-fired heat and power plants. Therefore, the aim of this study is to review exergy analysis in the heat and power sector, with respect to comparing performance, making assessments of, and suggesting improvements for, coal-fired, biomass-fired and co-fired coal and biomass heat and power plants.

\section{Exergy Analysis}

The aim of exergy analysis is to detect and evaluate the thermodynamic imperfections of a process quantitatively and indicate possible ways of improving it [22]. Thermodynamic imperfection, or irreversibility, is a function of the generation of entropy. Exergy analysis enables system designers and engineers to identify the parts with the highest entropy generation, providing them with key points on which to focus: they can then increase the efficiency of the system and, simultaneously, lower the negative impact exerted on the environment [23]. Achieving these two objectives involves making evaluations of, and optimizing, each component in the entire system using the mass, energy, entropy and exergy flow. For a steady-state process, these balances are expressed below [23,24].

The mass balance equation can be written in the rate form of Equation (1):

$$
\sum_{\mathrm{i}} \dot{\mathrm{m}}_{\mathrm{i}}=\sum_{\mathrm{e}} \dot{\mathrm{m}}_{\mathrm{e}}
$$

where $\dot{\mathrm{m}}_{\mathrm{i}}$ and $\dot{\mathrm{m}}_{\mathrm{e}}$ are the mass flow rates of the fluid entering and exiting the system, respectively. 
The energy rate balance for a steady-state system is expressed as Equation (2):

$$
\sum_{\mathrm{i}} \dot{\mathrm{E}}_{\mathrm{i}}+\dot{\mathrm{Q}}=\sum_{\mathrm{e}} \dot{\mathrm{E}}_{\mathrm{e}}+\dot{\mathrm{W}}
$$

where the energy rate entering and exiting the system is $\dot{\mathrm{E}}_{\mathrm{i}}$ and $\dot{\mathrm{E}}_{\mathrm{e}}$, respectively, $\dot{\mathrm{Q}}$ is the heat rate into the system and $\dot{W}$ is the work transfer rate performed by the system.

The entropy rate balance equation is given by Equation (3):

$$
\sum_{i} \dot{S}_{i}+\sum_{j} \frac{\dot{Q}_{j}}{T_{j}}+\dot{S}_{g e n}=\sum_{e} \dot{S}_{e}
$$

where $\dot{S}$ is the entropy rate of a flow and $\dot{S}_{\text {gen }}$ is the entropy generation rate.

The exergy rate balance for a system is calculated using Equation (4):

$$
\sum_{i} \dot{\mathrm{E}} \mathrm{x}_{\mathrm{i}}+\sum_{\mathrm{j}}\left[1-\frac{\mathrm{T}_{0}}{\mathrm{~T}_{\mathrm{j}}}\right] \dot{\mathrm{Q}}_{\mathrm{j}}=\sum_{\mathrm{e}} \dot{\mathrm{E}} \mathrm{x}_{\mathrm{e}}+\dot{\mathrm{W}}+\dot{\mathrm{I}}
$$

where $\dot{Q}_{j}$ is the heat transfer rate at temperature $T_{j}$ through the boundary at position $j$, $\dot{I}$ is the exergy destruction rate and $\mathrm{T}_{0}$ is the temperature of the reference environment.

Rearranging the exergy balance in Equation (4), the irreversible (or exergy destruction) rate can be expressed by Equation (5) thus:

$$
\dot{\mathrm{I}}=\sum_{\mathrm{i}} \dot{\mathrm{E}} \mathrm{x}_{\mathrm{i}}-\sum_{\mathrm{e}} \dot{\mathrm{E}} \mathrm{x}_{\mathrm{e}}+\sum_{\mathrm{j}}\left[1-\frac{\mathrm{T}_{0}}{\mathrm{~T}_{\mathrm{j}}}\right] \dot{\mathrm{Q}}_{\mathrm{j}}-\dot{\mathrm{W}}
$$

Assuming there are no heat losses since the insulation of each component in the system is good, the exergy associated with the heat transfer rate in the components is zero [25], and Equation (5) becomes:

$$
\dot{\mathrm{I}}=\sum_{\mathrm{i}} \dot{\mathrm{E}} \mathrm{x}_{\mathrm{i}}-\sum_{\mathrm{e}} \dot{\mathrm{E}} \mathrm{x}_{\mathrm{e}}-\dot{\mathrm{W}}
$$

The exergy destruction rate due to irreversibility in a system can also be given as Equation (7):

$$
\dot{\mathrm{I}}=\mathrm{T}_{0} \dot{\mathrm{S}}_{\text {gen }}
$$

The exergy rate associated with a flowing stream of matter contains physical, chemical, kinetic and potential exergy [26] according to Equation (8):

$$
\dot{\mathrm{Ex}}=\dot{\mathrm{m}}(\mathrm{ex})=\dot{\mathrm{m}}\left(\mathrm{ex} \mathrm{p}^{\mathrm{ph}}+\mathrm{ex}^{\mathrm{ch}}+\mathrm{ex}^{\mathrm{ke}}+\mathrm{ex}^{\mathrm{pe}}\right)
$$

where ex ${ }^{\mathrm{ke}}$ and ex $\mathrm{x}^{\mathrm{pe}}$ are exergy due to kinetic and potential energy, respectively, ex ${ }^{\mathrm{ph}}$ is the specific physical exergy and $\mathrm{ex}^{\mathrm{ch}}$ is the specific chemical exergy. Assuming that the changes in velocity and elevation of the flowing stream are negligible, then $\mathrm{ex}^{\mathrm{ke}}$ and $\mathrm{ex}^{\mathrm{pe}}$ can be discarded in the calculation of changes in exergy. The exergy flow rate of a stream is shown in Equation (9):

$$
\dot{\mathrm{E} x}=\dot{\mathrm{m}}(\mathrm{ex})=\dot{\mathrm{m}}\left(\mathrm{ex}^{\mathrm{ph}}+\mathrm{ex}^{\mathrm{ch}}\right)
$$


The specific physical exergy, ex ${ }^{\mathrm{ph}}$ is exergy due to the differences in the temperature and pressure of a system with respect to the reference environment [27]: it can be expressed by Equation (10) thus:

$$
\mathrm{ex}^{\mathrm{ph}}=\left(\mathrm{h}-\mathrm{h}_{0}\right)-\mathrm{T}_{\mathrm{o}}\left(\mathrm{s}-\mathrm{s}_{0}\right)
$$

where $h_{0}$ and $s_{0}$ are the specific enthalpy and the entropy respectively at the temperature of the reference environment.

The specific chemical exergy, ex ${ }^{\text {ch }}$ depends on the chemical composition of a substance in its particular state, and if it is in equilibrium with the reference environment [28]. For solid fuels, the specific chemical exergy can be estimated based on the elemental compositions of the fuel [29-37].

The second law of efficiency or exergy efficiency, $\eta_{\mathrm{ex}}$, of any system can be defined as the ratio of the exergy transfer rate associated with the output to the exergy transfer rate associated with the input of the system [3]. It is the best variable for evaluating the performance of a thermal system and its components [38], and is expressed here in Equation (11):

$$
\eta_{\text {ex }}=\frac{\dot{\mathrm{Ex}} \mathrm{x}_{\mathrm{p}}}{\dot{\mathrm{Ex}} \mathrm{x}_{\mathrm{f}}}=1-\frac{\dot{\mathrm{I}}+\dot{\mathrm{E} \mathrm{x}_{\mathrm{L}}}}{\dot{\mathrm{E} \mathrm{x}_{\mathrm{f}}}}
$$

where $\dot{E} x_{f}$ represents the fuel exergy rate, while $\dot{E} x_{p}$ and $\dot{E} x_{L}$ represent the exergy rate of the product and the rate of exergy loss from the system. If the heat losses from the components are neglected, then the exergy loss is zero [38] and Equation (11) can be rewritten as Equation (12):

$$
\eta_{\mathrm{ex}}=1-\frac{\dot{\mathrm{I}}}{\dot{\mathrm{m}}_{\mathrm{f}} \mathrm{ex}_{\mathrm{f}}}
$$

The first law efficiency or energy efficiency of a system is defined as the ratio of energy output rate to the energy input rate to system and is calculated using Equation (13) [18].

$$
\eta_{\mathrm{e}}=\frac{\dot{\mathrm{E}}_{\mathrm{o}}}{\dot{\mathrm{E}}_{\mathrm{i}}}=1-\frac{\dot{\mathrm{E}}_{\mathrm{L}}}{\dot{\mathrm{E}}_{\mathrm{i}}}
$$

where $\dot{E}_{\mathrm{O}}$ and $\dot{\mathrm{E}}_{\mathrm{i}}$ are energy output and energy input rate respectively. $\dot{\mathrm{E}}_{\mathrm{L}}$ is the rate of energy loss.

\section{Cycle Analysis of a Solid Fuel Fired Power Plant Using the Exergy Method}

The performance evaluation of the whole plant is done based on the components of the system. A detailed overview of the methods used for exergy analysis of each component of the solid fuel plant is given here using a modified Rankine cycle incorporated with feedwater heaters.

Generally, solid based fuels operate under thermodynamic cycles by using a working fluid in vapour form for the generation of power known as the "vapour power cycle" or the Rankine cycle. This cycle consists of four processes: reversible adiabatic pumping, constant-pressure heat transfer in the boiler, reversible adiabatic expansion in the turbine and constant-pressure heat transfer in the condenser [39]. Modifications of the Rankine cycle for optimal performance lead to the formation of the reheat, superheat and regenerative cycles, with the addition of feed water heaters and de-aerators. A process flow diagram of an advanced, modified Rankine cycle based on a solid-fuel combined heat and power plant is shown in Figure 1 [40], and includes both the heating of feedwater and reheating of steam.

Exergy analysis is applied to each component of the plant in order to evaluate the system's performance at steady state. The parts of the plant in question are: the combustion part of the boiler, heat exchangers in the boiler (HE), high pressure turbine (HPT), intermediate pressure turbine (IPT), low pressure turbine (LPT), condenser (Cond), condensate extraction pump (CEP), open feed water 
heater (OFWH), feed water pump 1 (FP1), closed feed water heater (CFWH) and feed water pump 2 (FP2). A detailed analysis is obtained by considering the mass, energy, entropy and exergy flow rate in the control volume of each individual system as well as the overall plant.

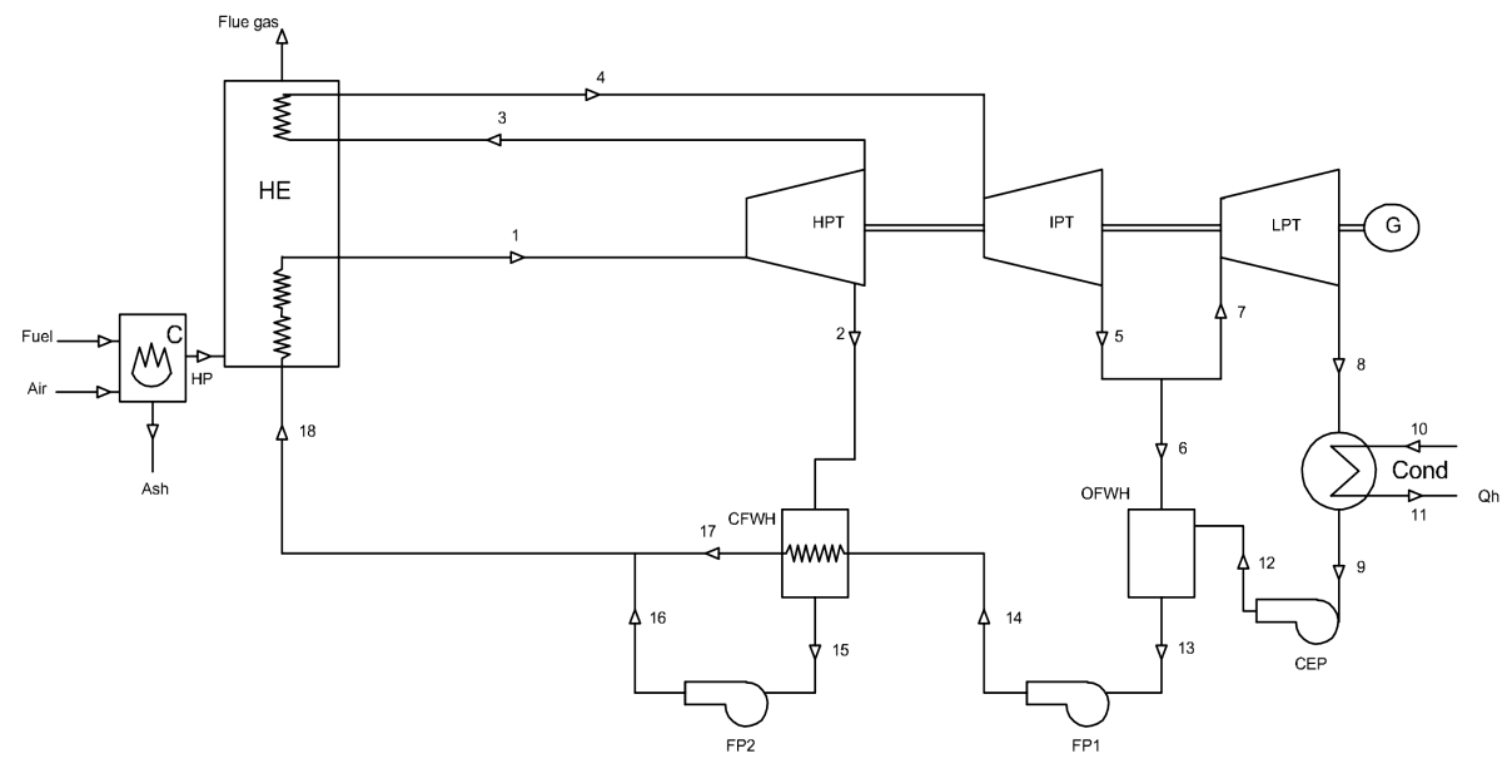

Figure 1. Flow diagram of solid fuel-fired heat and power plant model (modified from [40]).

\subsection{Boiler}

The boiler is divided into two parts: the combustor and the heat exchanger [12], as presented in Figure 1. If these are both assumed to be adiabatic, operating at steady state with negligible changes in their kinetic and potential energy, then each analysis in the boiler can be made by considering the mass, energy, entropy and exergy balance using the input and output conditions of the flows.

\subsubsection{Boiler Combustor (C)}

The exergy balance rate in the boiler combustor is given in Equation (14):

$$
\dot{\mathrm{m}}_{\mathrm{f}} \mathrm{ex}_{\mathrm{f}}+\dot{\mathrm{m}}_{\mathrm{a}} \mathrm{ex}_{\mathrm{a}}=\dot{\mathrm{m}}_{\mathrm{hp}} \mathrm{ex} \mathrm{hp}+\dot{\mathrm{m}}_{\mathrm{ash}} \mathrm{ex}_{\mathrm{ash}}+\dot{\mathrm{I}}_{\mathrm{C}}
$$

The exergy destruction rate for the boiler combustor is then calculated by Equation (15) thus:

$$
\dot{\mathrm{I}}_{\mathrm{C}}=\dot{\mathrm{m}}_{\mathrm{f}}\left(\mathrm{h}_{\mathrm{f}}-\mathrm{T}_{0} \mathrm{~s}_{\mathrm{f}}\right)+\dot{\mathrm{m}}_{\mathrm{a}}\left(\mathrm{h}_{\mathrm{a}}-\mathrm{T}_{0} \mathrm{~s}_{\mathrm{a}}\right)-\dot{\mathrm{m}}_{\mathrm{hp}}\left(\mathrm{h}_{\mathrm{hp}}-\mathrm{T}_{0} \mathrm{~s}_{\mathrm{hp}}\right)-\dot{\mathrm{m}}_{\mathrm{ash}}\left(\mathrm{h}_{\mathrm{ash}}-\mathrm{T}_{0} \mathrm{~s}_{\mathrm{ash}}\right)
$$

The exergy efficiency is expressed as Equation (16):

$$
\eta_{\mathrm{ex}, \mathrm{C}}=\frac{\dot{\mathrm{m}}_{\mathrm{hp}} \mathrm{ex}_{\mathrm{hp}}}{\dot{\mathrm{m}}_{\mathrm{f}} \mathrm{ex}_{\mathrm{f}}}
$$

\subsubsection{Boiler Heat Exchanger (HE)}

The exergy balance rate for the boiler heat exchanger can be written as Equation (17):

$$
\dot{\mathrm{m}}_{\mathrm{hp}} \mathrm{ex}_{\mathrm{hp}}+\dot{\mathrm{m}}_{1} \mathrm{ex}_{18}+\left(\dot{\mathrm{m}}_{1}-\dot{\mathrm{m}}_{2}\right) \mathrm{ex}_{3}=\dot{\mathrm{m}}_{\mathrm{fg}} \mathrm{ex}_{\mathrm{fg}}+\dot{\mathrm{m}}_{1} \mathrm{ex}_{1}+\left(\dot{\mathrm{m}}_{1}-\dot{\mathrm{m}}_{2}\right) \mathrm{ex}_{4}+\dot{\mathrm{I}}_{\mathrm{HE}}
$$


The exergy destruction rate is:

$$
\begin{aligned}
\dot{\mathrm{I}}_{\mathrm{HE}} & =\dot{\mathrm{m}}_{\mathrm{hp}}\left(\mathrm{h}_{\mathrm{hp}}-\mathrm{T}_{0} \mathrm{~s}_{\mathrm{hp}}\right)+\dot{\mathrm{m}}_{1}\left(\mathrm{~h}_{18}-\mathrm{T}_{0} \mathrm{~s}_{18}\right)+\left(\dot{\mathrm{m}}_{1}-\dot{\mathrm{m}}_{2}\right)\left(\mathrm{h}_{3}-\mathrm{T}_{0} \mathrm{~s}_{3}\right) \\
& -\dot{\mathrm{m}}_{\mathrm{fg}}\left(\mathrm{h}_{\mathrm{fg}}-\mathrm{T}_{0} \mathrm{~s}_{\mathrm{fg}}\right)-\dot{\mathrm{m}}_{1}\left(\mathrm{~h}_{1}-\mathrm{T}_{0} \mathrm{~s}_{1}\right)-\left(\dot{\mathrm{m}}_{1}-\dot{\mathrm{m}}_{1}\right)\left(\mathrm{h}_{4}-\mathrm{T}_{0} \mathrm{~s}_{4}\right)
\end{aligned}
$$

The exergy efficiency is given as:

$$
\eta_{\mathrm{ex}, \mathrm{HE}}=\frac{\dot{\mathrm{m}}_{1}\left(\mathrm{ex}_{1}-\mathrm{ex}_{18}\right)+\left(\dot{\mathrm{m}}_{1}-\dot{\mathrm{m}}_{2}\right)\left(\mathrm{ex}_{4}-\mathrm{ex}_{3}\right)}{\dot{\mathrm{m}}_{\mathrm{fg}}\left(\mathrm{ex}_{\mathrm{hp}}-\mathrm{ex}_{\mathrm{fg}}\right)}
$$

The overall boiler exergy efficiency is:

$$
\eta_{\mathrm{ex}, \mathrm{B}}=\frac{\dot{\mathrm{m}}_{1}\left(\mathrm{ex}_{1}-\mathrm{ex}_{18}\right)+\left(\dot{\mathrm{m}}_{1}-\dot{\mathrm{m}}_{2}\right)\left(\mathrm{ex}_{4}-\mathrm{ex}_{3}\right)}{\dot{\mathrm{m}}_{\mathrm{f}} \mathrm{ex}_{\mathrm{f}}}
$$

3.2. High Pressure Turbine (HPT)

The exergy balance rate for the high pressure turbine is:

$$
\dot{\mathrm{m}}_{1} \mathrm{ex}_{1}=\dot{\mathrm{m}}_{2} \mathrm{ex}_{2}+\left(\dot{\mathrm{m}}_{1}-\dot{\mathrm{m}}_{2}\right) \mathrm{ex}_{3}+\dot{\mathrm{W}}_{\mathrm{HPT}}+\dot{\mathrm{I}}_{\mathrm{HPT}}
$$

The exergy destruction rate in the system is expressed as:

$$
\dot{\mathrm{I}}_{\mathrm{HPT}}=\dot{\mathrm{m}}_{1}\left(\mathrm{~h}_{1}-\mathrm{T}_{0} \mathrm{~s}_{1}\right)-\dot{\mathrm{m}}_{2}\left(\mathrm{~h}_{2}-\mathrm{T}_{0} \mathrm{~s}_{2}\right)-\left(\dot{\mathrm{m}}_{1}-\dot{\mathrm{m}}_{2}\right)\left(\mathrm{h}_{3}-\mathrm{T}_{0} \mathrm{~s}_{3}\right)-\dot{\mathrm{W}}_{\mathrm{HPT}}
$$

The exergy efficiency is written as follows:

$$
\eta_{\mathrm{ex}, \mathrm{HPT}}=\frac{\dot{\mathrm{W}}_{\mathrm{HPT}}}{\dot{\mathrm{m}}_{1}\left(\mathrm{ex}_{1}-\mathrm{ex}_{2}\right)-\left(\dot{\mathrm{m}}_{1}-\dot{\mathrm{m}}_{2}\right) \mathrm{ex}_{3}}
$$

3.3. Intermediate Pressure Turbine (IPT)

The exergy balance rate is:

$$
\left(\dot{\mathrm{m}}_{1}-\dot{\mathrm{m}}_{2}\right) \mathrm{ex}_{4}=\left(\dot{\mathrm{m}}_{1}-\dot{\mathrm{m}}_{2}\right) \mathrm{ex}_{5}+\dot{\mathrm{W}}_{\mathrm{IPT}}+\dot{\mathrm{I}}_{\mathrm{IPT}}
$$

The exergy destruction rate is:

$$
\dot{\mathrm{I}}_{\mathrm{IPT}}=\left(\dot{\mathrm{m}}_{1}-\dot{\mathrm{m}}_{2}\right)\left(\mathrm{h}_{4}-\mathrm{T}_{0} \mathrm{~s}_{4}\right)-\left(\dot{\mathrm{m}}_{1}-\dot{\mathrm{m}}_{2}\right)\left(\mathrm{h}_{5}-\mathrm{T}_{0} \mathrm{~s}_{5}\right)-\dot{\mathrm{W}}_{\mathrm{IPT}}
$$

The exergy efficiency is:

$$
\eta_{\mathrm{ex}, \mathrm{IPT}}=\frac{\dot{\mathrm{W}}_{\mathrm{IPT}}}{\left(\dot{\mathrm{m}}_{1}-\dot{\mathrm{m}}_{2}\right)\left(\mathrm{ex}_{4}-\mathrm{ex}_{5}\right)}
$$

\subsection{Low Pressure Turbine (LPT)}

The exergy balance rate is:

$$
\left(\dot{\mathrm{m}}_{1}-\dot{\mathrm{m}}_{2}-\dot{\mathrm{m}}_{6}\right) \mathrm{ex}_{7}=\left(\dot{\mathrm{m}}_{1}-\dot{\mathrm{m}}_{2}-\dot{\mathrm{m}}_{6}\right) \mathrm{ex}_{8}+\dot{\mathrm{W}}_{\mathrm{LPT}}+\dot{\mathrm{I}}_{\mathrm{LPT}}
$$


The exergy destruction rate is:

$$
\dot{\mathrm{I}}_{\mathrm{LPT}}=\left(\dot{\mathrm{m}}_{1}-\dot{\mathrm{m}}_{2}-\dot{\mathrm{m}}_{6}\right)\left(\mathrm{h}_{7}-\mathrm{T}_{0} \mathrm{~s}_{7}\right)-\left(\dot{\mathrm{m}}_{1}-\dot{\mathrm{m}}_{2}-\dot{\mathrm{m}}_{6}\right)\left(\mathrm{h}_{8}-\mathrm{T}_{0} \mathrm{~s}_{8}\right)-\dot{\mathrm{W}}_{\mathrm{LPT}}
$$

The exergy efficiency is:

$$
\eta_{\mathrm{ex}}=\frac{\dot{\mathrm{W}}_{\mathrm{LPT}}}{\left(\dot{\mathrm{m}}_{1}-\dot{\mathrm{m}}_{2}-\dot{\mathrm{m}}_{6}\right)\left(\mathrm{ex}_{7}-\mathrm{ex}_{8}\right)}
$$

\subsection{Condenser}

The exergy balance rate is:

$$
\left(\dot{\mathrm{m}}_{1}-\dot{\mathrm{m}}_{2}-\dot{\mathrm{m}}_{6}\right) \mathrm{ex}_{8}+\dot{\mathrm{m}}_{10} \mathrm{ex}_{10}=\left(\dot{\mathrm{m}}_{1}-\dot{\mathrm{m}}_{2}-\dot{\mathrm{m}}_{6}\right) \mathrm{ex}_{9}+\dot{\mathrm{m}}_{11} \mathrm{ex}_{11}+\dot{\mathrm{I}}_{\text {Cond }}
$$

The exergy destruction rate is:

$$
\dot{\mathrm{I}}_{\text {Cond }}=\left(\dot{\mathrm{m}}_{1}-\dot{\mathrm{m}}_{2}-\dot{\mathrm{m}}_{6}\right)\left(\left(\mathrm{h}_{8}-\mathrm{T}_{0} \mathrm{~s}_{8}\right)-\left(\mathrm{h}_{9}-\mathrm{T}_{0} \mathrm{~s}_{9}\right)\right)+\dot{\mathrm{m}}_{10}\left(\left(\mathrm{~h}_{10}-\mathrm{T}_{0} \mathrm{~s}_{10}\right)-\left(\mathrm{h}_{11}-\mathrm{T}_{0} \mathrm{~s}_{11}\right)\right)
$$

The exergy efficiency is:

$$
\eta_{\mathrm{ex}, \text { Cond }}=\frac{\dot{\mathrm{m}}_{10}\left(\mathrm{ex}_{11}-\mathrm{ex}_{10}\right)}{\left(\dot{\mathrm{m}}_{1}-\dot{\mathrm{m}}_{2}-\dot{\mathrm{m}}_{6}\right)\left(\mathrm{ex}_{8}-\mathrm{ex}_{9}\right)}
$$

\subsection{Condensate Extraction Pump (CEP)}

The exergy balance rate is:

$$
\left(\dot{\mathrm{m}}_{1}-\dot{\mathrm{m}}_{2}-\dot{\mathrm{m}}_{6}\right) \mathrm{ex}_{9}=\left(\dot{\mathrm{m}}_{1}-\dot{\mathrm{m}}_{2}-\dot{\mathrm{m}}_{6}\right) \mathrm{ex}_{12}-\dot{\mathrm{W}}_{\mathrm{CEP}}+\dot{\mathrm{I}}_{\mathrm{CEP}}
$$

The exergy destruction rate is:

$$
\dot{\mathrm{I}}_{\mathrm{CEP}}=\left(\dot{\mathrm{m}}_{1}-\dot{\mathrm{m}}_{2}-\dot{\mathrm{m}}_{6}\right)\left(\mathrm{h}_{9}-\mathrm{T}_{0} \mathrm{~s}_{9}\right)-\left(\dot{\mathrm{m}}_{1}-\dot{\mathrm{m}}_{2}-\dot{\mathrm{m}}_{6}\right)\left(\mathrm{h}_{12}-\mathrm{T}_{0} \mathrm{~s}_{12}\right)+\dot{\mathrm{W}}_{\mathrm{CEP}}
$$

The exergy efficiency is:

$$
\eta_{\mathrm{ex}, \mathrm{CEP}}=\frac{\left(\dot{\mathrm{m}}_{1}-\dot{\mathrm{m}}_{2}-\dot{\mathrm{m}}_{6}\right)\left(\mathrm{ex}_{12}-\mathrm{ex}_{9}\right)}{\dot{\mathrm{W}}_{\mathrm{CEP}}}
$$

\subsection{Open Feed Water Heater (OFWH)}

The exergy balance rate is:

$$
\left(\dot{\mathrm{m}}_{1}-\dot{\mathrm{m}}_{2}-\dot{\mathrm{m}}_{6}\right) \mathrm{ex}_{12}+\dot{\mathrm{m}}_{6} \mathrm{ex}_{6}=\left(\dot{\mathrm{m}}_{1}-\dot{\mathrm{m}}_{2}\right) \mathrm{ex}_{13}+\dot{\mathrm{I}}_{\mathrm{OFWH}}
$$

The exergy destruction rate is:

$$
\dot{\mathrm{I}}_{\mathrm{OFWH}}=\left(\dot{\mathrm{m}}_{1}-\dot{\mathrm{m}}_{2}-\dot{\mathrm{m}}_{6}\right)\left(\mathrm{h}_{12}-\mathrm{T}_{0} \mathrm{~s}_{12}\right)+\dot{\mathrm{m}}_{6}\left(\mathrm{~h}_{6}-\mathrm{T}_{0} \mathrm{~s}_{6}\right)-\left(\dot{\mathrm{m}}_{1}-\dot{\mathrm{m}}_{2}\right)\left(\mathrm{h}_{13}-\mathrm{T}_{0} \mathrm{~s}_{13}\right)
$$


The exergy efficiency is:

$$
\eta_{\mathrm{ex}, \mathrm{OFWH}}=\frac{\left(\dot{\mathrm{m}}_{1}-\dot{\mathrm{m}}_{2}\right) \mathrm{ex}_{13}}{\left(\dot{\mathrm{m}}_{1}-\dot{\mathrm{m}}_{2}-\dot{\mathrm{m}}_{6}\right) \mathrm{ex}_{12}+\dot{\mathrm{m}}_{6} \mathrm{ex}_{6}}
$$

3.8. Feed Pump (FP1)

The exergy balance rate is:

$$
\left(\dot{\mathrm{m}}_{1}-\dot{\mathrm{m}}_{2}\right) \mathrm{ex}_{13}=\left(\dot{\mathrm{m}}_{1}-\dot{\mathrm{m}}_{2}\right) \mathrm{ex}_{14}-\dot{\mathrm{W}}_{\mathrm{FP} 1}+\dot{\mathrm{I}}_{\mathrm{FP} 1}
$$

The exergy destruction rate is:

$$
\dot{\mathrm{I}}_{\mathrm{FPI}}=\left(\dot{\mathrm{m}}_{1}-\dot{\mathrm{m}}_{2}\right)\left(\mathrm{h}_{13}-\mathrm{T}_{0} \mathrm{~s}_{13}\right)-\left(\dot{\mathrm{m}}_{1}-\dot{\mathrm{m}}_{2}\right)\left(\mathrm{h}_{14}-\mathrm{T}_{0} \mathrm{~s}_{14}\right)+\dot{\mathrm{W}}_{\mathrm{FP} 1}
$$

The exergy efficiency is:

$$
\eta_{\mathrm{ex}, \mathrm{FB} 1}=\frac{\left(\dot{\mathrm{m}}_{1}-\dot{\mathrm{m}}_{2}\right)\left(\mathrm{ex}_{14}-\mathrm{ex}_{13}\right)}{\dot{\mathrm{W}}_{\mathrm{FP} 1}}
$$

3.9. Closed Feed Water Heater (CFWH)

The exergy balance rate is:

$$
\dot{\mathrm{m}}_{2} \mathrm{ex}_{2}+\left(\dot{\mathrm{m}}_{1}-\dot{\mathrm{m}}_{2}\right) \mathrm{ex}_{14}=\dot{\mathrm{m}}_{2} \mathrm{ex}_{15}+\left(\dot{\mathrm{m}}_{1}-\dot{\mathrm{m}}_{2}\right) \mathrm{ex}_{17}+\dot{\mathrm{I}}_{\mathrm{CFWH}}
$$

The exergy destruction rate is:

$$
\dot{\mathrm{I}}_{\mathrm{CFWH}}=\dot{\mathrm{m}}_{2}\left(\left(\mathrm{~h}_{2}-\mathrm{T}_{0} \mathrm{~s}_{2}\right)-\left(\mathrm{h}_{15}-\mathrm{T}_{0} \mathrm{~s}_{15}\right)\right)+\left(\dot{\mathrm{m}}_{1}-\dot{\mathrm{m}}_{2}\right)\left(\left(\mathrm{h}_{14}-\mathrm{T}_{0} \mathrm{~s}_{14}\right)-\left(\mathrm{h}_{17}-\mathrm{T}_{0} \mathrm{~s}_{17}\right)\right)
$$

The exergy efficiency is:

$$
\eta_{\mathrm{ex}, \mathrm{CFWH}}=\frac{\left(\dot{\mathrm{m}}_{1}-\dot{\mathrm{m}}_{2}\right)\left(\mathrm{ex}_{17}-\mathrm{ex}_{14}\right)}{\dot{\mathrm{m}}_{2}\left(\mathrm{ex}_{2}-\mathrm{ex}_{15}\right)}
$$

3.10. Feed Pump (FP2)

The exergy balance rate is:

$$
\dot{\mathrm{m}}_{2} \mathrm{ex}_{15}=\dot{\mathrm{m}}_{2} \mathrm{ex}_{16}-\dot{\mathrm{W}}_{\mathrm{FP} 2}+\dot{\mathrm{I}}_{\mathrm{FP} 2}
$$

The exergy destruction rate is:

$$
\dot{\mathrm{I}}_{\mathrm{FP} 2}=\dot{\mathrm{m}}_{2}\left(\mathrm{~h}_{15}-\mathrm{T}_{0} \mathrm{~s}_{15}\right)-\dot{\mathrm{m}}_{2}\left(\mathrm{~h}_{16}-\mathrm{T}_{0} \mathrm{~s}_{16}\right)+\dot{\mathrm{W}}_{\mathrm{FP} 2}
$$

The exergy efficiency is:

$$
\eta_{\mathrm{ex}, \mathrm{FP} 2}=\frac{\dot{\mathrm{m}}_{2}\left(\mathrm{ex}_{16}-\mathrm{ex}_{15}\right)}{\dot{\mathrm{W}}_{\mathrm{FP} 2}}
$$


For a combined heat and power plant, the overall exergy efficiency can be written as [41-43]:

$$
\eta_{\mathrm{ex}, \mathrm{Pl}}=\frac{\left(\dot{\mathrm{w}}_{\mathrm{HPT}}+\dot{\mathrm{w}}_{\mathrm{IPT}}+\dot{\mathrm{w}}_{\mathrm{LPT}}-\dot{\mathrm{w}}_{\mathrm{CEP}}-\dot{\mathrm{w}}_{\mathrm{FP} 1}-\dot{\mathrm{w}}_{\mathrm{FP} 2}\right)+\dot{\mathrm{Ex}}_{\dot{\mathrm{Q}}_{\mathrm{h}}}}{\dot{\mathrm{Ex}}_{\mathrm{f}}}
$$

where $\dot{E} x_{Q_{h}}$ is the exergy flow rate associated to the heat produced, $Q_{h}$. Here, only the useful products have been included in comparison to the exergy input. The exergy of ash and flue gas are discarded as they do not represent a product flow.

\section{Application of Exergy Analysis in Solid Fuel-Fired Heat and Power Plants}

The use of exergy analysis on energy conversion processes has increased in the past years and has incorporated studies of different types of heat and power plant systems for improving the efficiency of existing power plants together with developing systems and systems under design for maximizing utilization of the energy produced. In this study, we have reviewed the application of exergy analysis as an evaluator of performance in coal-fired, biomass-fired and coal-biomass co-combustion-fired power plants.

\subsection{Coal-Fired Heat and Power Plants}

Coal supplies about $45 \%$ of the global electricity demand [44]. It is likely to continue as a key component of the fuel mix in the generation of power even though these plants account for over $28 \%$ of the total global emissions of carbon dioxide [45]. In order to maximize the utility of coal used in the production of energy, considerable efforts need to be made to enhance the capacity and efficiency of plants whilst simultaneously reducing their environmental impact and costs of power generation [46]. Improving both the efficiency and cost effectiveness of power plants can be achieved by reducing the thermodynamic inefficiencies associated with the system that result in a reduction of the $\mathrm{CO}_{2}$ emission per MW of electricity generated [47].

Exergy analysis has been proven to be a better way of measuring the efficiency of coal and reducing its environmental footprint by considering the effect of irreversibility in the process. A number of studies have been reported on the performance assessment and efficiency improvement of coal-based power plants using exergy analysis. Table 1 shows a summary of recent studies along with the most important conclusions that can be drawn from the application of exergy analysis when evaluating coal-fired heat and power plants.

These results identify the boiler as being the component of the plant with the highest exergy destruction as a result of the entropy generated due to irreversible combustion reactions. Exergy destruction in the combustor section of the boiler has been attributed to the chemical reaction between the fuel and air, while the large temperature difference between the combustion gases and the feedwater causes exergy destruction in the heat transfer section. The loss in the boiler in this particular case is over $50 \%$ of the total exergy destruction. As a result of the irreversibilities identified using exergy analysis, the exergetic efficiency is lower than the energetic efficiency, as can be seen in Table 1 . The exergy efficiency of the power plants studied ranges from $17 \%$ to $38 \%$. The results of the exergy destruction, heat loss and entropy generation in each component of a coal thermal power plant are summarized in Table 2 [23]. The energy analysis shows that highest energy loss occurs in the condenser, whereas the actual exergy destruction is in the boiler according to exergy analysis. The results also show that exergy destruction increases with increase in enropy generation. Hence, exergy analysis acounts for the entropy generated within the system, therefore, total exergy destruction is more than the heat loss. 
Table 1. Previous studies of exergy analysis applied to coal-fired heat and power plants.

\begin{tabular}{|c|c|c|c|c|c|c|c|c|}
\hline $\begin{array}{l}\text { Plant Capacity } \\
\text { (MW) }\end{array}$ & $\begin{array}{l}\text { Combustion } \\
\text { Technology }\end{array}$ & $\begin{array}{l}\text { Plant Output } \\
\text { Generation }\end{array}$ & Country & Exergy (\%) & $\begin{array}{c}\text { Energy } \\
\text { Efficiency (\%) }\end{array}$ & Aims & Major Results & Ref. \\
\hline 32 & Conventional & Electricity & India & 25.38 & 30.12 & $\begin{array}{l}\text { To conduct a thermodynamics } \\
\text { analysis, using the design data } \\
\text { of a coal-fired power plant } \\
\text { under construction, to identify } \\
\text { potential areas for making } \\
\text { improvements to performance. } \\
\text { To investigate the effects of } \\
\text { varying the operating } \\
\text { parameters on performance. }\end{array}$ & $\begin{array}{l}\text { The largest losses occurred in the } \\
\text { condenser when energy analysis was used. } \\
\text { When exergy analysis was applied, } \\
\text { however, the actual major losses were } \\
\text { found in the boiler, which has the highest } \\
\text { exergy destruction. This is due to heat } \\
\text { being transferred to the working fluid, the } \\
\text { combustion reaction and losses caused by } \\
\text { emissions of flue gases. Increasing the } \\
\text { steam pressure and temperature, and } \\
\text { reducing the pressure in the steam } \\
\text { condenser, increased the energy and } \\
\text { exergy efficiencies of the plant. }\end{array}$ & [23] \\
\hline 500 & Conventional & Electricity & Canada & 36 & 37 & $\begin{array}{l}\text { To examine sensitivity to } \\
\text { reasonable variations in } \\
\text { dead-state properties of } \\
\text { several energy and exergy } \\
\text { values. To examine the } \\
\text { results of energy and exergy } \\
\text { analyses of a complex device. }\end{array}$ & $\begin{array}{l}\text { The energy and exergy values were not } \\
\text { significantly sensitive to reasonable } \\
\text { variations in dead-state properties; the } \\
\text { main results of energy and exergy } \\
\text { analyses were not, generally speaking, } \\
\text { significantly sensitive to variations in } \\
\text { these properties. Variations in the } \\
\text { reference temperature considered, } \mathrm{T}_{0} \text {, } \\
\text { did not affect the overall results of the } \\
\text { energy and exergy efficiencies of the } \\
\text { plant significantly. }\end{array}$ & [26] \\
\hline 50 & Conventional & Electricity & India & 26.95 & 27 & $\begin{array}{l}\text { To conduct an exergy analysis } \\
\text { on the power generation of } \\
\text { Unit V, Thermal Power Station } \\
1 \text { of Neyveli Lignite Corp. Ltd. } \\
\text { (Tamil Nadu, India) in order } \\
\text { to discover the exergy losses } \\
\text { in various components of } \\
\text { the plant. }\end{array}$ & $\begin{array}{l}\text { The maximum energy loss ( } 39 \% \text { ) occurred } \\
\text { in the condenser while the total plant } \\
\text { exergy destruction was calculated as being } \\
73 \% \text {. The maximum exergy loss ( } 57.35 \%) \\
\text { occurred in the boiler, with } 42.73 \% \text { losses } \\
\text { being located in the combustion. }\end{array}$ & [27] \\
\hline
\end{tabular}


Table 1. Cont

\begin{tabular}{|c|c|c|c|c|c|c|c|c|}
\hline $\begin{array}{l}\text { Plant Capacity } \\
\text { (MW) }\end{array}$ & $\begin{array}{l}\text { Combustion } \\
\text { Technology }\end{array}$ & $\begin{array}{l}\text { Plant Output } \\
\text { Generation }\end{array}$ & Country & Exergy (\%) & $\begin{array}{c}\text { Energy } \\
\text { Efficiency (\%) }\end{array}$ & Aims & Major Results & Ref. \\
\hline 1.5 & Fluidized bed & Cogeneration & Turkey & 20 & - & $\begin{array}{l}\text { To perform an exergy analysis } \\
\text { of a cogeneration power plant, } \\
\text { located in Çankıri, that } \\
\text { generates electricity and steam } \\
\text { used for producing salt. }\end{array}$ & $\begin{array}{l}\text { The highest exergy destruction rate took } \\
\text { place in the boiler, which had } 85.89 \% \text { of } \\
\text { the total exergy loss in the system. } \\
\text { Improvements to the design parameters } \\
\text { (e.g., pressure, fluidized velocity, particle } \\
\text { size and geometry) as well as feeding the } \\
\text { coal from different points into the boiler } \\
\text { should affect the combustion and overall } \\
\text { plant efficiencies positively. }\end{array}$ & [48] \\
\hline 150 & Conventional & Electricity & Turkey & 35.19 & 37.88 & $\begin{array}{l}\text { To determine the effect of the } \\
\text { ambient temperature on the } \\
\text { irreversible losses and } \\
\text { efficiency in the Catalgzi } \\
\text { Power Plant in Zonguldak. }\end{array}$ & $\begin{array}{l}\text { The irreversibility rates of the boiler were } \\
\text { larger than for other components and } \\
\text { increased slightly, together with total } \\
\text { irreversibility rate, as the ambient } \\
\text { temperature was increased from } 278 \text { to } \\
308 \mathrm{~K} \text {, while that of the condenser } \\
\text { decreased with increasing ambient } \\
\text { temperature. The boiler was the major } \\
\text { source of exergy consumption (a result of } \\
\text { the chemical reaction between fuel and } \\
\text { air) and therefore has the largest potential } \\
\text { for improvement. }\end{array}$ & [49] \\
\hline 7.7 & Fluidized bed & Cogeneration & Turkey & 23 & 70 & $\begin{array}{l}\text { To analyse the thermodynamics } \\
\text { of a coal-fired fluidized bed } \\
\text { power plant to show the effects } \\
\text { that excess air, steam pressure } \\
\text { and type of coal have on the } \\
\text { first and second laws of } \\
\text { efficiency in the thermal } \\
\text { power plant. }\end{array}$ & $\begin{array}{l}\text { Second law analysis revealed that the } \\
\text { FBCC had the largest irreversibility, about } \\
80.4 \% \text { of the system's total exergy loss. } \\
\text { The chemical reaction }(72 \%) \text {, heat transfer } \\
\text { processes }(20 \%) \text { and physical transport } \\
(8 \%) \text { are the sources of irreversibilities in } \\
\text { the combustion process in FBCC. The } \\
\text { system's exergy efficiency increased with } \\
\text { steam pressure, while types of coal did } \\
\text { not affect the second law efficiency. As the } \\
\text { excess air value increased, the exergy and } \\
\text { energy efficiencies decreased, due to heat } \\
\text { losses being higher when the flow rates of } \\
\text { the flue gas increased and combustion } \\
\text { temperature decreased: these affect the } \\
\text { reaction rate of the fuel negatively. }\end{array}$ & [50] \\
\hline
\end{tabular}


Table 1. Cont

\begin{tabular}{|c|c|c|c|c|c|c|c|c|}
\hline $\begin{array}{c}\text { Plant Capacity } \\
\text { (MW) }\end{array}$ & $\begin{array}{l}\text { Combustion } \\
\text { Technology }\end{array}$ & $\begin{array}{l}\text { Plant Output } \\
\text { Generation }\end{array}$ & Country & Exergy $(\%)$ & $\begin{array}{c}\text { Energy } \\
\text { Efficiency (\%) }\end{array}$ & Aims & Major Results & Ref. \\
\hline- & Conventional & Electricity & - & 34 & 36 & $\begin{array}{l}\text { To investigate the effects of } \\
\text { feed water heaters on the } \\
\text { performance of a coal-fired } \\
\text { power plant using } \\
\text { thermodynamic analysis. }\end{array}$ & $\begin{array}{l}\text { For a single feed water heater, efficiency } \\
\text { was maximized at a bled steam } \\
\text { temperature ratio of } 0.4 \text {. The efficiency of } \\
\text { the cycle was high when the reheater } \\
\text { pressure was } 20 \%-25 \% \text { of the boiler } \\
\text { pressure. The exergetic loss in the boiler } \\
\text { decreased with the addition of feed } \\
\text { water heaters. }\end{array}$ & [51] \\
\hline 500 & Conventional & Electricity & Canada & 36 & 37 & $\begin{array}{l}\text { To compare coal and nuclear } \\
\text { electric generating stations } \\
\text { thermodynamically, using } \\
\text { energy and exergy analysis. }\end{array}$ & $\begin{array}{l}\text { In the coal-fired plant, } 67 \% \text { and } 33 \% \text { of the } \\
\text { exergy consumed was due to combustion } \\
\text { and heat transfer respectively, In the } \\
\text { nuclear power plant, } 5 \%, 0.9 \%, 0.1 \% \text { and } \\
94 \% \text { of the exergy destroyed was due } \\
\text { to the boiler, moderator cooler, } \\
\text { heavy-water pump and } \\
\text { reactor, respectively. }\end{array}$ & [54] \\
\hline
\end{tabular}


Table 1. Cont

\begin{tabular}{|c|c|c|c|c|c|c|c|c|}
\hline $\begin{array}{c}\text { Plant Capacity } \\
\text { (MW) }\end{array}$ & $\begin{array}{l}\text { Combustion } \\
\text { Technology }\end{array}$ & $\begin{array}{l}\text { Plant Output } \\
\text { Generation }\end{array}$ & Country & Exergy (\%) & $\begin{array}{c}\text { Energy } \\
\text { Efficiency (\%) }\end{array}$ & Aims & Major Results & Ref. \\
\hline $3 \times 210$ & Conventional & Electricity & Turkey & 31.95 & 37.01 & \multirow{9}{*}{$\begin{array}{l}\text { To make a comparative } \\
\text { analysis of the performance of } \\
\text { nine coal thermal power plants } \\
\text { from energetic and exergetic } \\
\text { aspects. }\end{array}$} & \multirow{9}{*}{$\begin{array}{l}\text { The plant with a capacity of } 320 \mathrm{MW} \\
\text { had the highest exergetic performance: } \\
\text { the exergy efficiency of a boiler with } \\
\text { a circulating bed combustor had the } \\
\text { highest value of all plant boilers. Boilers } \\
\text { are vital components because they have } \\
\text { the highest exergy losses in a plant: they } \\
\text { should therefore be investigated so that } \\
\text { the overall exergetic performance may } \\
\text { be enhanced. }\end{array}$} & \multirow{9}{*}{55} \\
\hline $4 \times 150$ & Conventional & Electricity & Turkey & 31.50 & 38.03 & & & \\
\hline $2 \times 150$ & Conventional & Electricity & Turkey & 35.19 & 37.88 & & & \\
\hline $3 \times 157$ & Conventional & Electricity & Turkey & 28.55 & 37.19 & & & \\
\hline $4 \times 360$ & Conventional & Electricity & Turkey & 32.46 & 42.64 & & & \\
\hline 210 & Conventional & Electricity & Turkey & 35.49 & 37.63 & & & \\
\hline $6 \times 165$ & Conventional & Electricity & Turkey & 32.35 & 36.08 & & & \\
\hline $5 \times 160.9$ & Conventional & Electricity & Turkey & 33.09 & 38.44 & & & \\
\hline $2 \times 160$ & $\begin{array}{l}\text { Circulating } \\
\text { fluidized bed }\end{array}$ & Electricity & Turkey & 37.88 & 42.12 & & & \\
\hline $3 \times 210$ & Conventional & Electricity & Turkey & 31.95 & 37.01 & $\begin{array}{l}\text { To determine the most } \\
\text { convenient point of extraction } \\
\text { of energy for use in district } \\
\text { heating/cooling in the } \\
\text { conventional coal-fired } \\
\text { Yatagan Thermal Power Plant, } \\
\text { using thermodynamic analysis } \\
\text { to examine the energetic and } \\
\text { exergetic performances. }\end{array}$ & $\begin{array}{l}\text { The most convenient point for extracting } \\
\text { steam in the plant analysed was found to } \\
\text { be the low-pressure turbine inlet stage. }\end{array}$ & [41] \\
\hline 500 & Conventional & Electricity & Canada & 36 & 37 & $\begin{array}{l}\text { To examine the effect of } \\
\text { increasing the reheat pressure } \\
\text { on the irreversibility rate and } \\
\text { exergy efficiency in a coal-fired } \\
\text { steam power plant. }\end{array}$ & $\begin{array}{l}\text { The irreversibility rate associated with } \\
\text { heat transfer in the steam generator } \\
\text { decreased as the reheat pressure increased. } \\
\text { However, the overall-plant exergy } \\
\text { efficiency decreased due to the large } \\
\text { decrease in the power output of the shaft. } \\
\text { The decrease in the plant's thermal and } \\
\text { exergy efficiencies over the range of reheat } \\
\text { pressures considered was nearly } 9.3 \% \text {. }\end{array}$ & [56] \\
\hline
\end{tabular}


Table 1. Cont.

\begin{tabular}{|c|c|c|c|c|c|c|c|c|}
\hline $\begin{array}{l}\text { Plant Capacity } \\
\text { (MW) }\end{array}$ & $\begin{array}{l}\text { Combustion } \\
\text { Technology }\end{array}$ & $\begin{array}{c}\text { Plant Output } \\
\text { Generation }\end{array}$ & Country & Exergy (\%) & $\begin{array}{c}\text { Energy } \\
\text { Efficiency (\%) }\end{array}$ & Aims & Major Results & Ref. \\
\hline 32.5 & Conventional & Electricity & India & 17.8 & - & $\begin{array}{l}\text { To analyse the performance } \\
\text { of a coal-fired stoker power } \\
\text { plant using exergy analysis. } \\
\text { To investigate the effects of } \\
\text { varying the operating } \\
\text { temperatures of the boiler } \\
\text { as well as the reference } \\
\text { temperature state. }\end{array}$ & $\begin{array}{l}\text { The boiler had the highest exergy } \\
\text { destruction rate, with } 77 \% \text { of the } \\
\text { total exergy loss being due to flue } \\
\text { gas emissions, flue gas temperature, } \\
\text { combustion reactions and heat } \\
\text { transfer to the steam. The efficiency } \\
\text { of the power plant increased from } \\
18 \% \text { to } 42 \% \text { when the temperature } \\
\text { of the exiting steam increased from } \\
723 \mathrm{~K} \text { to } 793 \mathrm{~K} \text {. Varying the } \\
\text { reference state temperature had } \\
\text { no significant impact on the plant's } \\
\text { overall performance. }\end{array}$ & [57] \\
\hline 250 & Conventional & Electricity & Bangladesh & 30.78 & - & $\begin{array}{l}\text { To investigate a coal-based } \\
\text { thermal plant operating at } \\
\text { sub-critical steam conditions } \\
\text { using thermodynamic } \\
\text { performance criteria. }\end{array}$ & $\begin{array}{l}\text { The maximum exergy losses } \\
\text { occurred in the boiler: the large } \\
\text { exergy loss was mainly due to the } \\
\text { combustion reaction and the high } \\
\text { temperature difference between } \\
\text { the combustion gas and the steam. }\end{array}$ & [58] \\
\hline 63 & $\begin{array}{l}\text { Circulating } \\
\text { fluidized bed }\end{array}$ & Electricity & India & 29.29 & 31.15 & $\begin{array}{l}\text { To establish the energy and } \\
\text { exergy flows of each } \\
\text { component in the coal-based } \\
\text { circulating fluidized bed boiler } \\
\text { in the Tuticorin Power Plant in } \\
\text { order to identify the major area } \\
\text { of exergy loss. }\end{array}$ & $\begin{array}{l}74 \% \text { of the total exergy loss occurred } \\
\text { in the furnace of the boiler system; } \\
54.1 \% \text { of the loss was located in the } \\
\text { furnace's combustion chamber. }\end{array}$ & [59] \\
\hline $4 \times 400$ & Conventional & Electricity & $\begin{array}{l}\text { Saudi } \\
\text { Arabia }\end{array}$ & 35.77 & - & $\begin{array}{l}\text { To evaluate the design and } \\
\text { performance of the existing } \\
\text { Ghazlan Power Plant using the } \\
\text { exergy concept. }\end{array}$ & $\begin{array}{l}\text { The major energy losses were due to } \\
\text { heat rejection in the condenser and } \\
\text { stack gases, while the highest exergy } \\
\text { losses of } 70.6 \% \text { of the total loss } \\
\text { occurred in the boiler. }\end{array}$ & [60] \\
\hline
\end{tabular}


Table 1. Cont

\begin{tabular}{|c|c|c|c|c|c|c|c|c|}
\hline $\begin{array}{l}\text { Plant Capacity } \\
\text { (MW) }\end{array}$ & $\begin{array}{l}\text { Combustion } \\
\text { Technology }\end{array}$ & $\begin{array}{l}\text { Plant Output } \\
\text { Generation }\end{array}$ & Country & Exergy (\%) & $\begin{array}{c}\text { Energy } \\
\text { Efficiency (\%) }\end{array}$ & Aims & Major Results & Ref. \\
\hline 7.7 & Fluidized bed & Cogeneration & Turkey & 23 & 70 & $\begin{array}{l}\text { To apply conventional and } \\
\text { advanced exergy analysis to } \\
\text { a fluidized bed coal } \\
\text { combustion (FBCC) and heat } \\
\text { recovery steam generator } \\
\text { (HRSG) in a textile plant. }\end{array}$ & $\begin{array}{l}\text { A total exergy destruction of } 5104 \mathrm{~kW} \\
\text { occurred in the system, the major part } \\
\text { of which }(4285 \mathrm{~kW}) \text { was in the FBCC. } \\
\text { The conventional exergy efficiencies in } \\
\text { the FBCC and HRSG were } 44.2 \% \text { and } \\
46.2 \% \text {, respectively, and } 53.1 \% \text { and } \\
48.1 \% \text {, respectively, for advanced } \\
\text { exergy efficiencies. }\end{array}$ & [61] \\
\hline $\begin{array}{l}145 \\
200 \\
300\end{array}$ & Conventional & Cogeneration & China & $\begin{array}{l}29.1 \\
32.2 \\
27.3\end{array}$ & $\begin{array}{c}58.2 \\
46.2 \\
73\end{array}$ & $\begin{array}{l}\text { To investigate the most } \\
\text { important operating } \\
\text { parameters affecting the } \\
\text { energetic and exergetic } \\
\text { efficiencies, and their influence } \\
\text { on the performance of three } \\
\text { different coal-fired combined } \\
\text { power (CHP) plants under } \\
\text { various operational conditions } \\
\text { in the district heating } \\
\text { (DH) system. }\end{array}$ & $\begin{array}{l}\text { The extraction flow rate and extraction } \\
\text { pressure were the most important } \\
\text { parameters of the energetic and } \\
\text { exergetic efficiencies, respectively, in } \\
\text { the three power plants. When the } \\
\text { extraction ratio increased, the energetic } \\
\text { efficiency increased, whereas the } \\
\text { exergetic efficiency decreased. A high } \\
\text { extraction ratio and a low extraction } \\
\text { pressure gave the best performance in } \\
\text { the CHP. A higher extraction pressure } \\
\text { led to a higher heat delivery. }\end{array}$ & [42] \\
\hline 280 & Conventional & Electricity & Australia & - & - & $\begin{array}{l}\text { To conduct an exergy analysis } \\
\text { of a coal-fired power plant in } \\
\text { central Queensland. }\end{array}$ & $\begin{array}{l}\text { The highest exergy destruction } \\
\text { occurred in the boiler, which had } 81 \% \\
\text { of the total exergy destruction in the } \\
\text { plant. This differs to the energy } \\
\text { balance, which showed that most of the } \\
\text { energy loss occurred in the condenser, } \\
\text { where } 69 \% \text { of the total was lost. } \\
\text { The exergy loss in the boiler was } \\
\text { a result of (i) its internal loss, (ii) the } \\
\text { loss in its blowdown stream and } \\
\text { (iii) the heat loss caused by the stream } \\
\text { of flue gas: the greatest exergy loss } \\
\text { occurred in the boiler's internal heat } \\
\text { transfer arrangement. A steam boiler } \\
\text { has a great potential for improving the } \\
\text { overall efficiency of a plant. }\end{array}$ & [62] \\
\hline
\end{tabular}


Table 2. Results from the analysis of a coal-fired thermal plant [23].

\begin{tabular}{cccc}
\hline Components & Exergy Destruction $\mathbf{( k W )}$ & Heat Loss $\mathbf{( k W )}$ & Entropy Generation $(\mathbf{k W} / \mathbf{K})$ \\
\hline Boiler & 73,046 & 12,663 & 3312.0 \\
Turbine & 6403 & 3242 & 17.2 \\
ACC (air cooled condenser) & 1622 & 33 & 3.3 \\
Deaerator & 886 & 71 & 1.4 \\
LP heater & 552 & 336 & 2.4 \\
HP heater & 759 & 65 & 2.7 \\
Boiler feed pump & 375 & 140 & 0.0 \\
Generator & 550 & 656 & 0.9 \\
Total & 84,193 & 50,456 & 3339.9 \\
\hline
\end{tabular}

Whilst the reference temperature does not have a noticeable effect on the energy efficiency [23], it does affect the exergy efficiency slightly, as shown in Table 3. This indicates that the surroundings of the system affect its performance when exergy analysis is used. Even though variations in the reference temperature, $T_{0}$, do not affect the overall exergy results significantly, it is important in determining the optimal operation condition in a given plant design [26]. An increase in the ambient temperature has a greater effect on the condenser compared to other components, as indicated in Table 4 [49].

Table 3. Variation in energy and exergy efficiencies at different reference temperatures [23].

\begin{tabular}{ccc}
\hline Temperature (K) & Exergy Efficiency (\%) & Energy Efficiency (\%) \\
\hline 273 & 25.3970 & 30.12 \\
283 & 25.3920 & 30.12 \\
293 & 25.3884 & 30.12 \\
303 & 25.3850 & 30.12 \\
313 & 25.3806 & 30.12 \\
323 & 25.3760 & 30.12 \\
\hline
\end{tabular}

Table 4. The exergy rate of fuel and irreversibility rates of a power plant, $\mathrm{kW}$, at different reference temperatures [49].

\begin{tabular}{cccccccc}
\hline Reference Temperature & $\mathbf{2 7 8} \mathbf{~ K}$ & $\mathbf{2 8 3} \mathbf{~ K}$ & $\mathbf{2 8 8} \mathbf{~ K}$ & $\mathbf{2 9 3} \mathbf{~ K}$ & $\mathbf{2 9 8} \mathbf{~ K}$ & $\mathbf{3 0 3 ~ K}$ & $\mathbf{3 0 8} \mathbf{~ K}$ \\
\hline Fuel exergy rate & 473,500 & 473,500 & 473,500 & 473,500 & 473,500 & 473,500 & 473,500 \\
Irreversibility rate of boiler & 262,520 & 262,561 & 268,602 & 271,643 & 274,684 & 277,725 & 280,766 \\
Irreversibility rate of turbine & 35,594 & 35,941 & 36,288 & 36,636 & 36,983 & 37,330 & 37,678 \\
Irreversibility rate of condenser & 9330 & 7982 & 6871 & 4607 & 2186 & 960 & 373 \\
Irreversibility rate of feed water heaters & 5256 & 5314 & 5371 & 5428 & 5486 & 5543 & 5601 \\
Irreversibility rate of pumps & 1014 & 1028 & 1042 & 1056 & 1070 & 1084 & 1098 \\
Irreversibility rate of pipe & 1418 & 1393 & 1367 & 1342 & 1317 & 1291 & 1266 \\
Total Irreversibility rate & 315,132 & 317,218 & 319,542 & 320,711 & 321,725 & 323,934 & 326,780 \\
\hline
\end{tabular}

Taniguchi et al. [63] conducted exergy analyses of coal combustion processes with air temperatures entering the combustion chamber higher than the ambient temperature. They found that an increase in the temperature of the combustion air increases exergy efficiency. The decrease in the amount of excess air reduces flue gas losses and improves the combustion temperature [48]. Feedwater heaters can be installed to decrease the temperature difference between the flue gases and the working fluid [51]; both of these measures decrease the irreversibilities in the boiler. Operation of a power plant at full load has been shown to increase the combustion efficiency of the system and the exergy efficiency of the plant $[52,53]$, indicating that power plants operating at their rated capacity are more economical than when operating at part loads [23]. The performance of the boiler system and the exergy efficiency increase with an increase in the steam pressure and temperature and number of feed water heaters, but a decrease in pressure in the condenser and reheater [23,51,52], while utilization of the rejected 
heat from the condensers as employed in the cogeneration systems improves the overall efficiency of the system [54].

The adoption of fluidized bed combustion firing technologies has been suggested as a means of improving the performance of energy conversion systems since (i) their heating surfaces located in the combustion chamber have high heat transfer rates and (ii) their combustion efficiency is superior to conventional firing systems [55]. Moreover, a fluidized bed boiler has the capacity of burning fuel mixtures with widely differing characteristics. Its low combustion temperature minimizes $\mathrm{NO}_{x}$, and the usage of adsorbent in the bed permits the capture of sulphur [64].

\subsection{Heat and Power Plants Fired by Biomass-Based Fuels}

Biomass energy is derived from plant and animal material, such as wood and wood waste, agricultural crops and their waste by-products, solid municipal refuse, animal offal, waste from food processing units, aquatic plants and algae [65]. The resource known as biomass can be considered as being renewable material in which the energy of sunlight is stored in the form of chemical bonds; when the bonds between adjacent carbon, hydrogen and oxygen molecules are broken by digestion, combustion or decomposition, these substances can release their stored chemical energy [66].

The reduction in the use of coal fuels, and the need to find alternatives to fossil fuels in order to decrease $\mathrm{CO}_{2}$ emissions, have attracted more interest in using biomass fuels as the energy carrier since biomass is perceived as being a carbon-neutral source $[67,68]$ : biomass is thus regarded a suitable source of energy [69]. However, the overall efficiencies of biomass-fired power plants are relatively low [19,70]. Only a few papers in the literature have discussed exergy analysis applied to biomass-based heat and power plants-these are summarized in Table 5.

Li et al. [67] used conventional exergy analysis to find the sources of irreversibilities and to identify exergy destruction in the various different components of the biomass boiler. They also used advanced exergy analysis to provide comprehensive information about the avoidable exergy destruction for each component, as well as for the whole system. Their results showed that a combustion chamber with a higher degree of heat absorption has a higher exergy in the specified boiler components and that, in a biomass boiler system, the combustion process is where most of the exergy destruction that is avoidable can be found.

Kamate and Gangavati [71] applied exergy analysis to two types of steam turbines to examine the effective utilization of cogeneration power plants in the sugar industry. They found that the efficiency of the plant using a non-condensing steam turbine (back pressure steam turbine) with energy and exergy efficiencies of 0.863 and 0.307 respectively, was higher than that of a plant using an extraction (condensing) steam turbine with energy and exergy efficiencies of 0.682 and 0.260 respectively, because the former does not reject heat in the condensation process. However, when a greater amount of electricity is needed, the latter is preferred.

The generation of entropy occurs mainly in the combustion process, which prompted Baloyi et al. [72] to examine the change in its rate as a function of the air to fuel (AF) ratio in an adiabatic combustor, using wood as the source of fuel. They showed that the entropy generation rate reaches a minimum at an $\mathrm{AF}$ of 4.9 and equivalence ratio of 1.64 .

The performances of biomass multi-generation and cogeneration power plants have also been evaluated. Soltani et al. [28] investigated a biomass multi-generation energy system that produces electricity, steam, hot water, district heating and timber heating: significant increases in both the energy and exergy efficiencies were observed in the biomass multi-generation systems compared to conventional systems. A fuel energy savings ratio of $8.2 \%$ was reported by Kamate and Gangavati [43] for a biomass cogeneration plant over the generation of heat and power in two separate plants. 
Table 5. Previous studies of exergy analysis applied to biomass-fired heat and power plants.

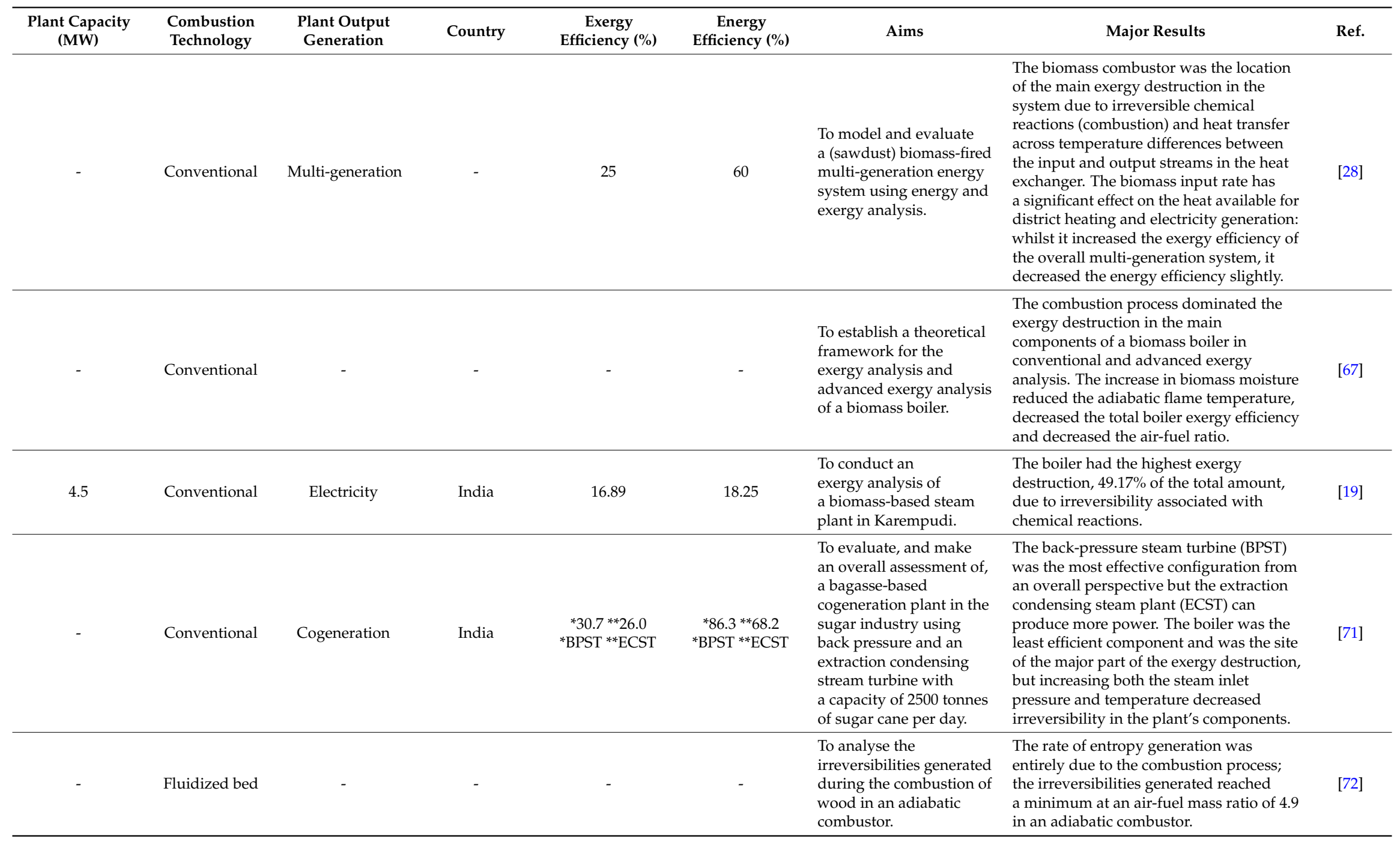


Table 5. Cont

\begin{tabular}{|c|c|c|c|c|c|c|c|c|}
\hline $\begin{array}{l}\text { Plant Capacity } \\
\text { (MW) }\end{array}$ & $\begin{array}{l}\text { Combustion } \\
\text { Technology }\end{array}$ & $\begin{array}{l}\text { Plant Output } \\
\text { Generation }\end{array}$ & Country & $\begin{array}{c}\text { Exergy } \\
\text { Efficiency (\%) }\end{array}$ & $\begin{array}{c}\text { Energy } \\
\text { Efficiency (\%) }\end{array}$ & Aims & Major Results & Ref. \\
\hline 44 & Conventional & Cogeneration & India & 25 & 65 & $\begin{array}{l}\text { To evaluate } \\
\text { bagasse-based } \\
\text { cogeneration of power } \\
\text { based on a sugar factory } \\
\text { in Belgaum with } \\
\text { a capacity of } 10,000 \text { tons } \\
\text { of sugar cane per day } \\
\text { (TCD) using energy and } \\
\text { exergy analysis. }\end{array}$ & $\begin{array}{l}\text { The major exergy destruction was found } \\
\text { in the boiler, where } 71 \% \text { of the fuel exergy } \\
\text { input was destroyed. Energy losses } \\
\text { occurred mainly in the boiler exhaust and } \\
\text { condenser, where } 35 \mathrm{MW} \text { and } 27 \mathrm{MW} \\
\text { were lost to the environment, respectively. } \\
\text { The plant's fuel energy savings ratio for } \\
\text { the co-generation plant is } 8.2 \% \text { over } \\
\text { separate generation. }\end{array}$ & [43] \\
\hline- & - & - & - & - & - & $\begin{array}{l}\text { To analyse critically, } \\
\text { and calculate correctly, } \\
\text { the efficiency of energy } \\
\text { recovered from waste } \\
\text { incineration in the new } \\
\text { waste framework } \\
\text { directive. To compare } \\
\text { the energy recovery } \\
\text { efficiency to the more } \\
\text { scientifically-based } \\
\text { approach of } \\
\text { exergy efficiency. }\end{array}$ & $\begin{array}{l}\text { The average energy recovery efficiencies } \\
\text { calculated for CHP plants, plants } \\
\text { producing mainly electricity and plants } \\
\text { only producing heat were } 0.71,0.49 \text { and } \\
0.64 \text {, respectively, whilst the average } \\
\text { exergy efficiencies for these plants were } \\
20.9 \%, 19.4 \% \text { and } 18.8 \% \text {, respectively. } \\
\text { The average energy recovery efficiency of } \\
\text { WTE plants is higher in northern Europe } \\
\text { than in southern, as a result of the } \\
\text { cogeneration technology that is mostly } \\
\text { used there. The energy recovery efficiency } \\
\text { in a WTE plant does not take into account } \\
\text { the effect of the plant's size and the } \\
\text { influence of climate conditions. } \\
\text { The exergy efficiency is a reliable measure } \\
\text { of the calculation of efficiency of energy } \\
\text { recovery from waste incineration. }\end{array}$ & [74] \\
\hline
\end{tabular}


Different methods have been applied to calculate the efficiency of the incineration of municipal solid waste. Solheimslid et al. [73] used the chemical exergy of solid biomass by employing correlations, the chemical exergy obtained from the combustion equation and the absolute entropy to determine the exergy efficiency of municipal waste in a combined heat and power plant, and found both results to be in good agreement. Grosso et al. [74] examined the energy recovery efficiency, reported in the Waste Frame Directive (Directive 2008/98/EC), which accounts for the production of both power and heat. According to the directive, the energy recovery efficiency must be equal to, or exceed, 0.60 for waste incineration plants to be classified as energy recovery, rather than waste disposal, units. They analysed and compared the energy recovery efficiency to the exergy efficiency in the form of energy recovery criteria for different types of waste incineration plants in Europe, and found out that only the exergy efficiency can be considered a reliable measure.

\subsection{Biomass and Coal Co-Fired Heat and Power Plant}

Co-firing biomass in coal-fired boilers is regarded as being the most cost-effective approach for utilising biomass to generate power [75] because it requires little initial investment: the combustion technologies used in biomass co-firing plants are similar to those used in existing coal-fired plants [76]. Three different methods are used in biomass co-firing technology: direct, indirect and parallel co-firing. In the first method, biomass is fed directly into a boiler furnace with coal whilst the second entails a combination of gasification and combustion: the biomass is gasified and the product gas is fed into a boiler furnace containing the coal. The third method involves the biomass being burnt in a separate boiler to generate steam, which is then used in a power plant together with coal [77]. Selecting the appropriate co-firing option depends on the type of biomass available and site-specific factors, such as the types of coal handling equipment used and the arrangement of the coal firing systems installed [78,79].

Biomass co-fired with coal in traditional coal-fired boilers presents one combination of utilising fossil and renewable energy that derives the greatest benefit from both types of fuel; it leads to an effective reduction in $\mathrm{CO}_{2}$ and $\mathrm{SO}_{x}$ emissions, and often $\mathrm{NO}_{x}$ emissions too. It represents an attractive alternative for reducing emissions of greenhouse gas from coal-fired boilers [80]. Coal-biomass co-firing prevents the concentration of chlorine, which can otherwise result in the formation of harmful alkaline and chlorine compounds on the heat transfer surfaces in boilers [81]. Progress has been made over the past years in developing the co-ultilization of biomass fuels in coal-fired boiler plants [82]. Exergy analysis can nevertheless be used to evaluate performance in order to identify both the magnitude and the locations of imperfections in the process, with the aim of improving the efficiency of the plant. Reports pertaining to exergy analyses of biomass co-combustion processes are very few and far between: Table 6 shows a summary of previous work performed in this field.

Biomass co-combustion is considered as a measure for reducing $\mathrm{CO}_{2}$ emissions. However, the exergy losses due to irreversibility from biomass co-firing are larger than for coal-based power plants. This irrervisibility has led to decreases in the exergy efficiencies of both the boiler and the overall co-combustion plant [83]: the gas exiting the furnace has a lower temperature due to a reduction in the exergy input to the plant. Applying biomass co-firing to a fluidized bed shows that the velocity of the fluidized bed does not influence the exergy efficiency [84].

The Soma coal thermal power plant in Turkey was modified to operate as both a direct and parallel co-firing biomass plant; performance evaluation shows that biomass parallel combustion performs better, from both technical and environmental aspects, than direct co-firing which suffers from problems of corrosion and fouling in the boiler [25]. As a result of the direct contact that occurs between biomass and coal in the direct co-firing method, the alkali metals and chlorine from the biomass reduced the melting temperature of the ash: the result was slagging at the furnace walls of the boiler and a possible decrease in the efficiency of the plant [85]. 
Table 6. Previous studies of exergy analysis applied to coal-biomass co-combustion heat and power plants

\begin{tabular}{|c|c|c|c|c|c|c|c|c|}
\hline $\begin{array}{l}\text { Plant Capacity } \\
\text { (MW) }\end{array}$ & $\begin{array}{l}\text { Combustion } \\
\text { Technology }\end{array}$ & $\begin{array}{c}\text { Plant Output } \\
\text { Generation }\end{array}$ & Country & $\begin{array}{c}\text { Exergy } \\
\text { Efficiency }(\%)\end{array}$ & $\begin{array}{c}\text { Energy } \\
\text { Efficiency (\%) }\end{array}$ & Aims & Major Results & Ref. \\
\hline 165 & Conventional & Electricity & Turkey & 29.04 & 35.91 & $\begin{array}{l}\text { To investigate the technical and } \\
\text { environmental feasibility of } \\
\text { direct and parallel co-firing of } \\
\text { biomass * with Soma Lignite } \\
\text { Corp. Ltd. in the Soma Thermal } \\
\text { Power Plant, using exergy } \\
\text { analysis. * corn cobs, cotton gin } \\
\text { and olive pits. }\end{array}$ & $\begin{array}{l}\text { Both the direct and parallel co-firing of } \\
\text { biomass decreased the consumption rate } \\
\text { of lignite and reduced the plant's } \\
\text { emissions of } \mathrm{CO}_{2}, \mathrm{SO}_{2} \text { and dust } \\
\text { significantly. The largest exergy } \\
\text { destruction occurred in the boiler. } \\
\text { Parallel co-firing offered better technical } \\
\text { and environmental performances than } \\
\text { direct co-firing. }\end{array}$ & [25] \\
\hline- & Conventional & Electricity & - & 32.26 & - & $\begin{array}{l}\text { To conduct an exergy analysis of } \\
\text { a biomass * co-fired based } \\
\text { conventional pulverized coal } \\
\text { (bituminous and lignite) power } \\
\text { plant. * chicken litter, pine } \\
\text { sawdust, refuse-derived fuel and } \\
\text { rice husks. }\end{array}$ & $\begin{array}{l}\text { The largest exergy destruction occurred } \\
\text { in the boiler, due to chemical reactions } \\
\text { and heat transfer across a large } \\
\text { temperature difference between the } \\
\text { product gas and the feed water, with the } \\
\text { combustor having the highest degree of } \\
\text { destruction. The irreversibility rates of } \\
\text { the plant decreased as the content of } \\
\text { biomass in the fuel blend increased. } \\
\text { However, the exergy efficiencies of the } \\
\text { boiler and the overall plant decreased as } \\
\text { the co-firing increased. Although } \\
\text { biomass co-firing is not advantageous } \\
\text { from a thermodynamic perspective, it } \\
\text { helps reduce environmental emissions } \\
\text { and enhances the finances of the plant. }\end{array}$ & [83] \\
\hline 1.0 & Fluidized bed & Electricity & - & 32.9 & - & $\begin{array}{l}\text { To apply the exergy method to } \\
\text { the nine experimental results } \\
\text { obtained from the pilot plant, } \\
\text { modelled on bubbling fluidized } \\
\text { bed co-combustion, using } \\
\text { biomass * and low grade Spanish } \\
\text { coal. * pine chips, i.e., } \\
\text { wood waste. }\end{array}$ & $\begin{array}{l}\text { The exergy destroyed ranged from } \\
48.4 \% \text { to } 56.2 \% \text { of the exergy input, with } \\
\text { highest irreversibility found in the } \\
\text { combustion process. The performance of } \\
\text { the plant may be improved by reducing } \\
\text { the exit temperature of the flue gas by } \\
\text { the addition of a heat exchanger; heat } \\
\text { loss to the environment can be reduced } \\
\text { by insulating the combustion chamber. }\end{array}$ & [84] \\
\hline
\end{tabular}




\section{Discussion}

The performance assessment of energy from solid fuels used for generation of heat and power has been reviewed. An effective utilization of this energy in the heat and power plant is needed: as the fuel conversion efficiencies investigated are low. The use of energy efficiency to evaluate the performance of the system is not adequate as the energy method does not identify degradation of the energy quality during the energy conversion processes. As a result of this inaccuracy, the energy efficiencies are higher than the exergy efficiencies.

The difference between the energy and exergy efficiencies is observed in the heat and power plant, Figure 2, while little variation is seen in the power plant, Figure 3, where the data used is collected from Tables 1, 5 and 6 . The produced heat, often distributed as water around $100{ }^{\circ} \mathrm{C}$ has a low energy quality (low exergy) but represents rather high energy content.

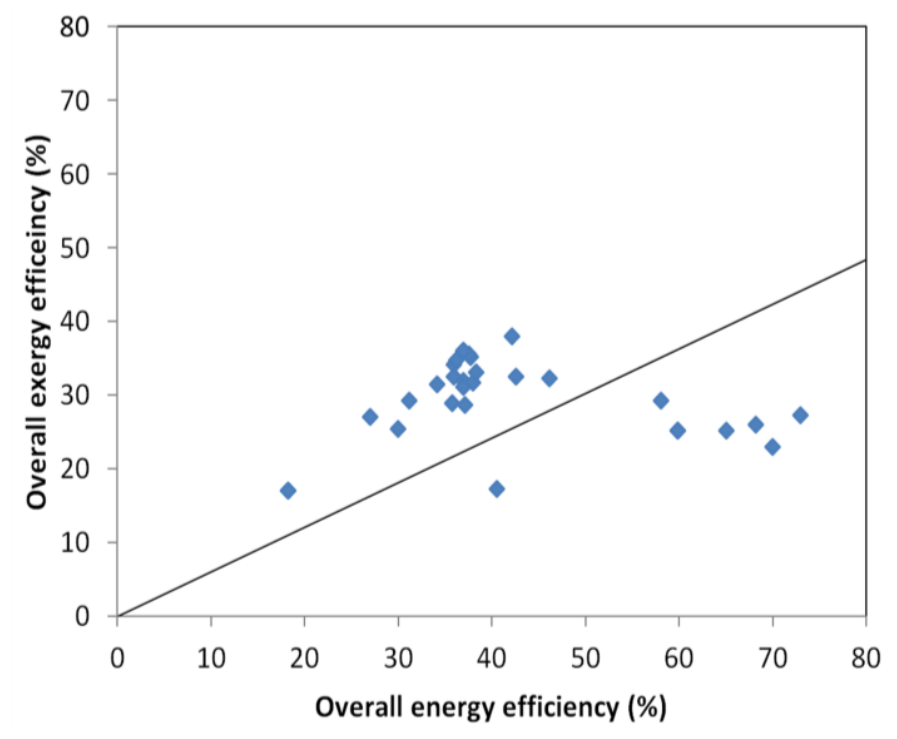

Figure 2. Variation of exergy and energy efficiency in different combined heat and power plants.

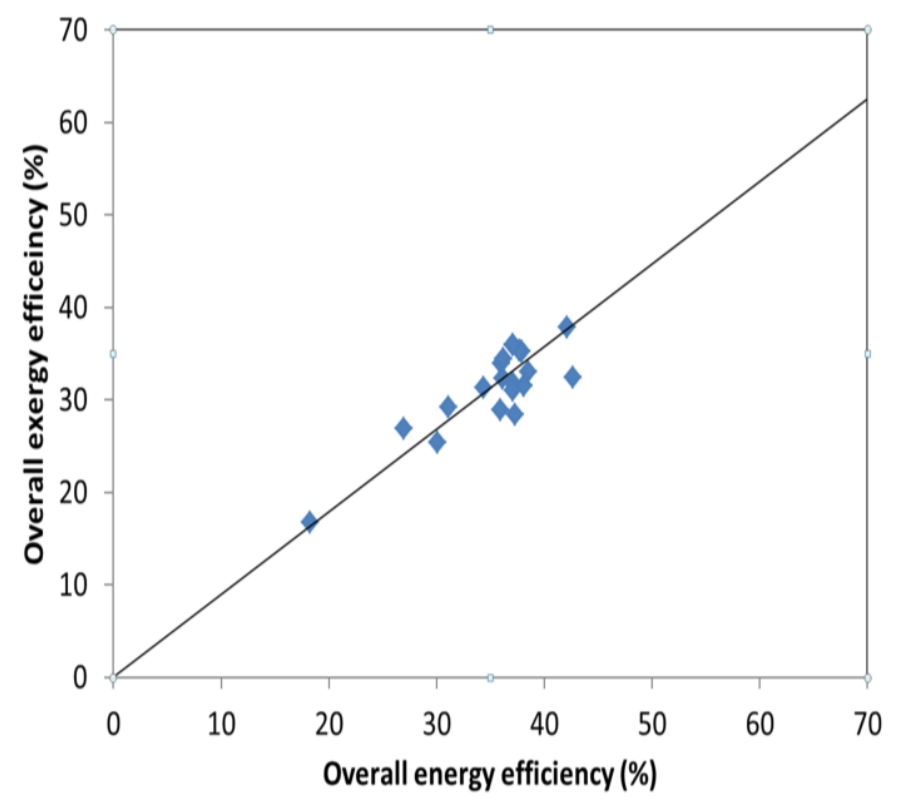

Figure 3. Variation of exergy and energy efficiency in different power plants. 
The performance of the whole plant is based on the individual components of the system. Therefore, identification of the component with highest inefficiencies is the first step for performance improvement of the overall plant. According to the energy analysis, the major energy losses in a power plant are due to the heat rejection in the condenser as a result of the large enthalpy difference between the turbine and the condenser: here, second law analysis shows that less than $6 \%$ of the total exergy loss stems from the condenser while as much as $69 \%$ of the total energy loss is found in this component [62]. From the exergy analysis, the highest degree of exergy destruction occurs in the boiler (combustion and heat transfer) with over $50 \%$ of the total irreversibility in the plant. Figure 4 shows the effect of boiler efficiency on the performance of the overall plant, where the plant data is taken from Tables 1 , 5 and 6 . The result indicates that an increase in the boiler efficiency will increase the overall exergy efficiency of the plant.

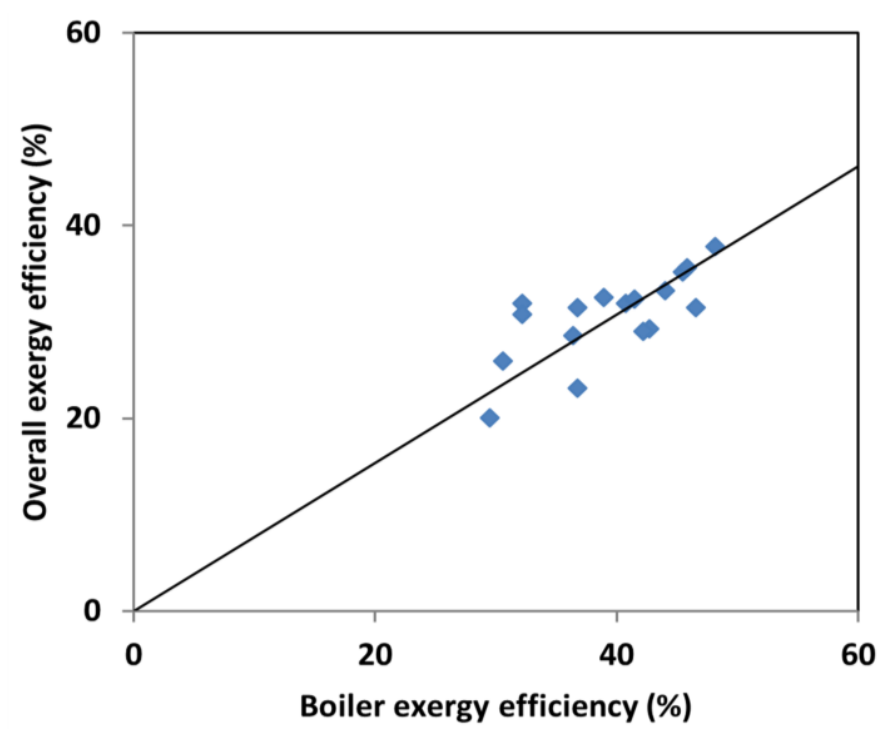

Figure 4. Effect of the boiler efficiency on the overall plant exergy efficiency.

The performance evaluations of the solid fuel-fired heat and power plants reviewed, shows in general, that the coal-fired plant has highest exergy efficiency compared with the other solid fuels. This is as a result of higher operating temperature and pressure. However, the $\mathrm{CO}_{2}$ emissions associated with the system have an impact on the environment as a greenhouse gas. The emissions can be reduced by integrating the plant with carbon capture and storage [86]. But adopting this technology means extra cost and more energy is consumed during the process, which leads to reduction in the efficiency of the plant [47].

The biomass-based fuels on the other hand account for about $14 \%$ of the energy utilize in the world [87]. It remains the main source of energy for more than half of the world's population [88]. Although, biomass has a lower efficiency than coal; it is a suitable and renewable energy option that provides clean gas fuels presently and in the future $[89,90]$.

Co-combustion of biomass and coal could decrease the consumption rate of coal as well as reduce the environmental impact from coal-fired plant. Biomass contains only a small amount of nitrogen and sulphur, which will reduce $\mathrm{NO}_{2}$ and $\mathrm{SO}_{2}$ emissions associated with coal [91]. Co-firing also gives higher exergy efficiency than the biomass-based plant. However, co-firing of biomass in the existing coal-fired plant decreases the boiler and overall exergy efficiency due to increased moisture content in the biomass, which reduces the furnace exit gas temperature [83]. Moreover, it increases corrosion and ash deposition in the system, and if co-utilization of biomass fuel in coal-fired plant is not carefully designed, it will involve risk of power outages [80]. 
Different improvement measures have been suggested by the past studies in order to reduce exergy destruction. Though excess air is needed for complete combustion, the amount should be minimized because an increase in excess air will reduce the adiabatic flame temperature and decrease the exergy efficiency of the boiler [67] as well as the overall exergy efficiency of the plant [53]. Installation of feedwater heaters will decrease the temperature difference of the flue gas and feedwater, and will reduce irreversibilities encountered in the boiler heat exchanger. The decrease in pressure of the condenser as well as increase in steam pressure and temperature will reduce exergy destruction and increase the overall system performance. However, increase in the temperature is limited by the boiler tube's oxidation temperature and allowable stress [67]. Moreover, the benefit of higher revenue as a result of increase in performance of the plant due to the increase in temperature and installation of feedwater heaters should be balanced against the increase in the capital cost to ensure that the pay-back period on the investment is favourable [23]. A plant operating at its full capacity is shown to be more economical and with higher exergy efficiency than those operating at part loads [52]. Because at full capacity, the heat absorbed in the combustion chamber will increase together with the efficiency of the boiler. However, this may not always be true for the combined heat and power plant: here, extraction ratio had a significant influence on the performance of the plant. As the plant with the smallest extraction ratio will have the highest exergy efficiency and lowest energy efficiency [42].

The use of advanced exergy-based method for evaluation of inefficiencies in the thermal conversion systems should be recommended. This method accounts for the avoidable and unavoidable exergy destruction associated with the plant and interaction between the components. The unavoidable part of exergy destruction cannot be improved, even using the best possible solution with available technology [44], as a result of limitation in the design specifications of the plant. The efforts to improve the plant should then be concentrated on the avoidable part so that the real thermodynamic inefficiencies and their causes can be identified [92].

\section{Conclusions}

Exergy analysis is a reliable method that can be used for the design, optimization, performance evaluation and calculation of efficiency of a solid fuel-fired heat and power plant. The exergetic method enables the main sources of loss to be identified, quantifies the irreversibilities that result from the entropy generated and provides direction for improving performance in the system. The application of exergy analysis should be extended to biomass-based and biomass co-combustion fired power plants so that important improvements can be made, because limited research work has been carried out in these sectors. Turkey and India are the two major countries where exergy analysis has been applied to solid fuel power plants, the majority of which are coal-fired. The results of the present review indicate that extensive research should focus on the combustion and heat transfer processes in boilers in order to optimise the performance of solid fuel-fired heat and power plants.

Acknowledgments: Financial support from University of Borås, Sweden and TETFund Nigeria through Michael Okpara University of Agriculture, Umudike, Abia State, Nigeria is greatly appreciated.

Author Contributions: Francis Chinweuba Eboh is responsible for the literature survey and writing of the manuscript. Peter Ahlström and Tobias Richards supervised the research work.

Conflicts of Interest: The authors declare no conflict of interest.

\section{Nomenclature}

$\dot{\mathbf{E}}$

$\dot{\mathbf{E x}}$

ex

$\mathrm{h}$

$\dot{\mathbf{I}}$ energy rate $(\mathrm{kW})$

exergy rate $(\mathrm{kW})$

specific exergy $(\mathrm{kJ} / \mathrm{kg})$

specific enthalpy $(\mathrm{kJ} / \mathrm{kg})$

irreversibility rate or exergy destruction rate $(\mathrm{kW})$ 


\begin{tabular}{|c|c|}
\hline$\dot{\mathbf{m}}$ & mass flow rate $(\mathrm{kg} / \mathrm{s})$ \\
\hline$\dot{\mathbf{Q}}$ & heat transfer rate $(\mathrm{kW})$ \\
\hline$\dot{\mathbf{S}}$ & entropy rate $(\mathrm{kW} / \mathrm{K})$ \\
\hline $\mathrm{s}$ & specific entropy (kJ/kgK) \\
\hline $\mathrm{T}$ & temperature $(\mathrm{K})$ \\
\hline$\dot{\mathbf{W}}$ & work transfer rate $(\mathrm{kW})$ \\
\hline \multicolumn{2}{|c|}{ Subscripts } \\
\hline a & air \\
\hline f & fuel \\
\hline $\mathrm{fg}$ & flue gas \\
\hline hp & hot product \\
\hline $\mathrm{L}$ & lost \\
\hline $\mathrm{p}$ & product \\
\hline pl & plant \\
\hline e & exit \\
\hline $\mathrm{o}$ & out \\
\hline gen & generation \\
\hline i & input \\
\hline 0 & reference environment or dead state \\
\hline \multicolumn{2}{|c|}{ Superscripts } \\
\hline $\mathrm{Ch}$ & chemical \\
\hline $\mathrm{Ke}$ & kinetic energy \\
\hline $\mathrm{Pe}$ & potential energy \\
\hline $\mathrm{Ph}$ & physical \\
\hline \multicolumn{2}{|c|}{ Abbreviations } \\
\hline $\mathrm{B}$ & boiler \\
\hline $\mathrm{C}$ & combustor \\
\hline CEP & condensate extraction pump \\
\hline CFWH & closed feed water heater \\
\hline $\mathrm{CHP}$ & combined heat and power \\
\hline Cond & condenser \\
\hline $\mathrm{FP}$ & feed water pump \\
\hline HE & heat exchanger \\
\hline HPT & high pressure turbine \\
\hline IPT & intermediate pressure turbine \\
\hline LPT & low pressure turbine \\
\hline OFWH & open feed water heater \\
\hline $\mathrm{HP}$ & hot product \\
\hline WTP & waste-to-energy \\
\hline \multicolumn{2}{|c|}{ Greek letter } \\
\hline$\eta$ & efficiency \\
\hline
\end{tabular}

\section{References}

1. Gupta, M.K.; Kaushik, S.C.; Ranjan, K.R.; Panwar, N.L.; Reddy, V.S.; Tyagi, S.K. Thermodynamic performance evaluation of solar and other thermal power generation systems: A review. Renew. Sustain. Energy Rev. 2015, 50, 567-582. [CrossRef]

2. Pazheri, F.R.; Othman, M.F.; Malik, N.H. A review on global renewable electricity scenario. Renew. Sustain. Energy Rev. 2014, 31, 835-845. [CrossRef]

3. Ranjan, K.R.; Kaushik, S.C. Energy, exergy and thermo-economic analysis of solar distillation systems: A review. Renew. Sustain. Energy Rev. 2013, 27, 709-723. [CrossRef]

4. Luis, P.; Van der Bruggen, B. Exergy analysis of energy-intensive production processes: Advancing towards a sustainable chemical industry. J. Chem. Technol. Biotechnol. 2014, 89, 1288-1303. [CrossRef]

5. Hinderink, A.P.; Arons, J.D.; Van der Kooi, H. On the efficiency and sustainability of the process industry. Green Chem. 1999, 1, G176-G180. [CrossRef] 
6. Gallo, W.L.R.; Milanez, L.F. Choice of a reference state for exergetic analysis. Energy 1990, 15, $113-121$. [CrossRef]

7. Ray, T.K.; Datta, A.; Gupta, A.; Ganguly, R. Exergy-based performance analysis for proper O\&M decisions in a steam power plant. Energy Convers. Manag. 2010, 51, 1333-1344.

8. Gaggioli, R.A.; Wepfer, W.J. Exergy economics. Energy 1980, 5, 823-837. [CrossRef]

9. Luis, P. Exergy as a tool for measuring process intensification in chemical engineering. J. Chem. Technol. Biotechnol. 2013, 88, 1951-1958. [CrossRef]

10. Rosen, M.A.; Dincer, I. On exergy and environmental impact. Int. J. Energy Res. 1997, 21, 643-654. [CrossRef]

11. Richards, T.; Pavletic, C.; Pettersson, J. Efficiencies of $\mathrm{NaOH}$ production methods in a Kraft pulp mill. Int. J. Energy Res. 2009, 33, 1341-1351. [CrossRef]

12. Saidur, R.; Ahamed, J.U.; Masjuki, H.H. Energy, exergy and economic analysis of industrial boilers. Energy Policy 2010, 38, 2188-2197. [CrossRef]

13. Dewulf, J.; Van Langenhove, H.; Muys, B.; Bruers, S.; Bakshi, B.R.; Grubb, G.F.; Paulus, D.M.; Sciubba, E. Exergy: Its potential and limitations in environmental science and technology. Environ. Sci. Technol. 2008, 42, 2221-2232. [CrossRef] [PubMed]

14. Bejan, A. Fundamentals of exergy analysis, entropy generation minimization, and the generation of flow architecture. Int. J. Energy Res. 2002, 26, 545-565. [CrossRef]

15. Ni, M.; Leung, D.Y.C.; leung, M.K.H.; Sumathy, K. An overview of hydrogen production from biomass. Fuel Process. Technol. 2006, 87, 461-472. [CrossRef]

16. Sudheer, P.D.V.N.; David, Y.; Chae, C.G.; Kim, Y.J.; Baylon, M.G.; Baritugo, K.-A.; Kim, T.W.; Kim, M.-S.; Na, J.G.; PARK, S.J. Advances in the biological treatment of coal for synthetic natural gas and chemicals. Korean J. Chem. Eng. 2016, 33, 2788-2801. [CrossRef]

17. Zhang, L.; Xu, C.; Champagne, P. Overview of recent advances in thermo-chemical conversion of biomass. Energy Convers. Manag. 2010, 51, 969-982. [CrossRef]

18. Kaushik, S.C.; Reddy, V.S.; Tyagi, S.K. Energy and exergy analyses of thermal power plants: A review. Renew. Sustain. Energy Rev. 2011, 15, 1857-1872. [CrossRef]

19. Naik, R.J.; Gupta, B.; Sharma, G.S. Exergy analysis of 4.5 MW biomass-based steam power plant. J. Human Soc. Sci. 2012, 1, 1-4.

20. Demirbas, A. Combustion systems for biomass fuel. Energy Sources A Recovery Util. Environ. Eff. 2007, 29, 303-312. [CrossRef]

21. Saidur, R.; Boroumandjazi, G.; Mekhilef, S.; Mohammed, H.A. A review on exergy analysis of biomass based fuels. Renew. Sustain. Energy Rev. 2012, 16, 1217-1222. [CrossRef]

22. Szargut, J.; Morris, D.R.; Steward, F.R. Exergy Analysis of Thermal, Chemical, and Metallurgical Processes; Hemisphere: New York, NY, USA, 1988.

23. Regulagadda, P.; Dincer, I.; Naterer, G.F. Exergy analysis of a thermal power plant with measured boiler and turbine losses. Appl. Therm. Eng. 2010, 30, 970-976. [CrossRef]

24. Dincer, I.; Rosena, M.A. Exergy, Environment and Sustainable Development; Elsevier: Oxford, UK, 2007.

25. Amirabedin, E.; McIlveen-Wright, D. A feasibility study of co-firing biomass in the thermal power plant at Soma in order to reduce emissions: An exergy approach. Int. J. Environ. Res. 2013, 7, 139-154.

26. Rosen, M.A.; Dincer, I. Effect of varying dead-state properties on energy and exergy analyses of thermal systems. Int. J. Therm. Sci. 2004, 43, 121-133. [CrossRef]

27. Ganapathy, T.; Alagumurthi, N.; Gakkhar, R.P.; Murugesan, K. Exergy analysis of operating lignite-fired thermal power plant. J. Eng. Sci. Technol. Rev. 2009, 2, 123-130.

28. Soltani, R.; Dincer, I.; Rosen, M.A. Thermodynamic analysis of a novel multigeneration energy system based on heat recovery from a biomass CHP cycle. Appl. Therm. Eng. 2015, 89, 90-100. [CrossRef]

29. Rant, Z. Towards the estimation of specific exergy of fuels. Allg. Wärmetech. 1961, 10, 172-176. (In German)

30. Szargut, J.; Styrylska, T. Approximate evaluation of the exergy of fuels (in German). Brennst. Warme Kraft 1964, 16, 589-596.

31. Eisermann, W.; Johnson, P.; Conger, W.L. Estimating thermodynamic properties of coal, char, tar and ash. Fuel Process. Technol. 1980, 3, 39-53. [CrossRef]

32. Shieh, J.H.; Fan, L.T. Estimation of energy (enthalpy) and exergy (availability) contents in structurally complicated materials. Energy Sources 1982, 6, 1-46. [CrossRef] 
33. Ikumi, S.; Luo, C.D.; Wen, C.Y. Method of estimating entropies of coals and coal liquids. Can. J. Chem. Eng. 1982, 60, 551-555. [CrossRef]

34. Bilgen, S.; Kaygusuz, K. The calculation of the chemical exergies of coal-based fuels by using the higher heating values. Appl. Energy 2008, 85, 776-785. [CrossRef]

35. Song, G.; Shen, L.; Xiao, J. Estimating specific chemical exergy of biomass from basic analysis data. Ind. Eng. Chem. Res. 2011, 50, 9758-9766. [CrossRef]

36. Song, G.; Xiao, J.; Zhao, H.; Shen, L. A unified correlation for estimating specific chemical exergy of solid and liquid fuels. Energy 2012, 40, 164-173. [CrossRef]

37. Eboh, F.C.; Ahlström, P.; Richards, T. Estimating the specific chemical exergy of municipal solid waste. Energy Sci. Eng. 2016, 4, 217-231. [CrossRef]

38. Tsatsaronis, G.; Park, M.-H. On avoidable and unavoidable exergy destructions and investment costs in thermal systems. Energy Convers. Manag. 2002, 43, 1259-1270. [CrossRef]

39. Borgnakke, C.; Sonntag, R. Fundamentals of Thermodynamics; John Wiley \& Sons, Inc.: Danvers, MA, USA; Chichester, UK, 2008.

40. Singh, O. Applied Thermodynamics; New Age International (P) Ltd.: New Delhi, India, 2003.

41. Erdem, H.H.; Dagdas, A.; Sevilgen, S.H.; Cetin, B.; Akkaya, A.V.; Sahin, B.; Teke, I.; Gungor, C.; Atas, S. Thermodynamic analysis of an existing coal-fired power plant for district heating/cooling application. Appl. Therm. Eng. 2010, 30, 181-187. [CrossRef]

42. Liao, C.; Ertesvåg, I.S.; Zhao, J. Energetic and exergetic efficiencies of coal-fired CHP (combined heat and power) plants used in district heating systems of China. Energy 2013, 57, 671-681. [CrossRef]

43. Kamate, S.; Gangavati, P. Energy and exergy analysis of a 44-MW bagasse-based cogeneration plant in India. Cogener. Distrib. Gener. J. 2010, 25, 35-51. [CrossRef]

44. Wang, L.; Yang, Y.; Morosuk, T.; Tsatsaronis, G. Advanced thermodynamic analysis and evaluation of a supercritical power plant. Energies 2012, 5, 1850-1863. [CrossRef]

45. Coal Industry Advisory Board: IEA Programme of Power Generation from Coal. Measuring and Reporting Efficiency Performance and $\mathrm{CO}_{2}$ Emissions, OECD/IEA. 2010. Available online: https://www.iea.org/ciab/ papers/power_generation_from_coal.pdf (accessed on 5 July 2016).

46. Fu, C.; Anantharaman, R.; Jordal, K.; Gundersen, T. Thermal efficiency of coal-fired power plants: From theoretical to practical assessments. Energy Convers. Manag. 2015, 105, 530-544. [CrossRef]

47. Olaleye, A.K.; Wang, M.; Kelsall, G. Steady state simulation and exergy analysis of supercritical coal-fired power plant with $\mathrm{CO}_{2}$ capture. Fuel 2015, 151, 57-72. [CrossRef]

48. Gürtürk, M.; Oztop, H.F. Exergy analysis of a circulating fluidized bed boiler cogeneration power plant. Energy Convers. Manag. 2016, 120, 346-357. [CrossRef]

49. Kopac, M.; Hilalci, A. Effect of ambient temperature on the efficiency of the regenerative and Reheat Çatalağzı power plant in Turkey. Appl. Therm. Eng. 2007, 27, 1377-1385. [CrossRef]

50. Eskin, N.; Gungor, A.; Özdemir, K. Effects of operational parameters on the thermodynamic performance of FBCC steam power plant. Fuel 2009, 88, 54-66. [CrossRef]

51. Srinivas, T.; Gupta, A.V.S.S.K.S.; Reddy, B.V. Generalized thermodynamic analysis of steam power cycles with ' $n$ ' number of feedwater heaters. Int. J. Thermodyn. 2007, 10, 177-185.

52. Sengupta, S.; Datta, A.; Duttagupta, S. Exergy analysis of a coal-based $210 \mathrm{MW}$ thermal power plant. Int. J. Energy Res. 2007, 31, 14-28. [CrossRef]

53. Pattanayak, L.; Sahu, J.N. Steady state modeling on energy and exergy analysis of a pulverized coal fired thermal power plant. Asia-Pac. J. Chem. Eng. 2015, 10, 876-884. [CrossRef]

54. Rosen, M.A. Energy and exergy-based comparison of coal-fired and nuclear steam power plants. Int. J. Exergy 2001, 3, 180-192. [CrossRef]

55. Erdem, H.H.; Akkaya, A.V.; Cetin, B.; Dagdas, A.; Sevilgen, S.H.; Sahin, B.; Teke, I.; Gungor, C.; Atas, S. Comparative energetic and exergetic performance analyses for coal-fired thermal power plants in Turkey. Int. J. Therm. Sci. 2009, 48, 2179-2186. [CrossRef]

56. Rosen, M.A.; Tang, R. Assessing and improving the efficiencies of a steam power plant using exergy analysis. Part 2: Improvements from modifying reheat pressure. Int. J. Exergy 2006, 4, 377-390. [CrossRef]

57. Khoodaruth, A.; Aljundi, I.H. Performance analysis of a grate stroker coal-fired power plant based on the second law of thermodynamics. Int. J. Exergy 2015, 1, 84-103. [CrossRef] 
58. Nazrul Islam, A.K.M.; Alam, F.; Ashraful Islam, M. Energy and exergy analysis of a coal-based thermal power plant. In Proceedings of the 6th Bangladesh Society of Mechanical Engineers International Conference on Thermal Engineering, Dhaka, Bangladesh, 19-21 December 2014.

59. Ashok, K.T.; Chandramouli, R.; Jothikumar, K. Exergy analysis of a coal based $63 \mathrm{MW}$ circulating fluidized bed boiler-A case study. J. Appl. Sci. 2014, 14, 1515-1521.

60. Habib, M.A.; Said, S.A.M.; Al-Bagawi, J.J. Thermodynamic performance analysis of the Ghazlan power plant. Energy 1995, 20, 1121-1130. [CrossRef]

61. Callak, M.; Balkan, F.; Hepbasli, A. Avoidable and unavoidable exergy destructions of a fluidized bed coal combustor and a heat recovery steam generator. Energy Convers. Manag. 2015, 98, 54-58. [CrossRef]

62. Mahamud, R.; Khan, M.M.K.; Rasul, M.G.; Leinster, M.G. Exergy analysis and efficiency improvement of a coal-fired thermal power in Queensland. In Thermal Power Plants: Advanced Applications; Rasul, M.G., Ed.; lnTech: Rijeka, Croatia, 2013; Chapter 1.

63. Taniguchi, H.; Mouri, K.; Nakahara, T.; Arai, N. Exergy analysis on combustion and energy conversion processes. Energy 2005, 30, 111-117. [CrossRef]

64. Oktay, Z. Investigation of coal-fired power plants in Turkey and a case study: Can plant. Appl. Therm. Eng. 2009, 29, 550-557. [CrossRef]

65. Demirbaş, A. Biomass resource facilities and biomass conversion processing for fuels and chemicals. Energy Convers. Manag. 2001, 42, 1357-1378. [CrossRef]

66. McKendry, P. Energy production from biomass (Part 1): Overview of biomass. Bioresour. Technol. 2002, 83, 37-46. [CrossRef]

67. Li, C.; Gillum, C.; Toupin, K.; Donaldson, B. Biomass boiler energy conversion system analysis with the aid of exergy-based methods. Energy Convers. Manag. 2015, 103, 665-673. [CrossRef]

68. Abbasi, T.; Abbasi, S.A. Biomass energy and the environmental impacts associated with its production and utilization. Renew. Sustain. Energy Rev. 2010, 14, 919-937. [CrossRef]

69. McKendry, P. Energy production from biomass (Part 2): Conversion technologies. Bioresour. Technol. 2002, 83, 47-54. [CrossRef]

70. Athari, H.; Soltani, S.; Seyed Mahmoudi, S.M.; Rosen, M.A.; Morosuk, T. Exergoeconomic analysis of a biomass post-firing combined-cycle power plant. Energy 2014, 77, 553-561. [CrossRef]

71. Kamate, S.C.; Gangavati, P.B. Exergy analysis of cogeneration power plants in sugar industries. Appl. Therm. Eng. 2009, 29, 1187-1194. [CrossRef]

72. Baloyi, J.; Bello-Ochende, T.; Meyer, J.P. Thermodynamic optimisation and computational analysis of irreversibilities in a small-scale wood-fired circulating fluidised bed adiabatic combustor. Energy 2014, 70, 653-663. [CrossRef]

73. Solheimslid, T.; Harneshaug, H.K.; Lümmen, N. Calculation of first-law and second-law-efficiency of a Norwegian combined heat and power facility driven by municipal waste incineration-A case study. Energy Convers. Manag. 2015, 95, 149-159. [CrossRef]

74. Grosso, M.; Motta, A.; Rigamonti, L. Efficiency of energy recovery from waste incineration, in the light of the new waste framework directive. Waste Manag. 2010, 30, 1238-1243. [CrossRef] [PubMed]

75. Tillman, D.A. Biomass co-firing: The technology, the experience, the combustion consequences. Biomass Bioenergy 2000, 19, 365-384. [CrossRef]

76. Khorshidi, Z.; Ho, M.T.; Wiley, D.E. Techno-economic study of biomass co-firing with and without $\mathrm{CO}_{2}$ capture in an Australian black coal-fired power plant. Energy Procedia 2013, 37, 6035-6042. [CrossRef]

77. Nussbaumer, T. Combustion and co-combustion of biomass: Fundamentals, technologies, and primary measures for emission reduction. Energy Fuels 2003, 17, 1510-1521. [CrossRef]

78. Basu, P.; Butler, J.; Leon, M.A. Biomass co-firing options on the emission reduction and electricity generation costs in coal-fired power plants. Renew. Energy 2011, 36, 282-288. [CrossRef]

79. Obernberger, I.; Thek, I. The Pellet Handbook; Earthscan: London, UK, 2010.

80. Baxter, L.; Koppejan, J. Biomass-Coal Co-Combustion: Opportunity for Affordable Renewable Energy. 2004. Available online: http://www.ieabcc.nl/publications/paper_cofiring.pdf (accessed on 1 July 2016).

81. The European Bioenergy Networks (EUBIONET): Biomass Co-Firing- an Efficient Way to Reduce Greenhouse Gas Emissions. 2003. Available online: https://ec.europa.eu/energy/sites/ener/files/documents/2003_ cofiring_eu_bionet.pdf (accessed on 8 July 2003). 
82. Al-Mansour, F.; Zuwala, J. An evaluation of biomass co-firing in Europe. Biomass Bioenergy 2010, 34, 620-629. [CrossRef]

83. Mehmood, S.; Reddy, B.V.; Rosen, M.A. Exergy analysis of a biomass co-firing based pulverized coal power generation system. Int. J. Green Energy 2015, 12, 461-478. [CrossRef]

84. Martín, C.; Villamañán, M.A.; Chamorro, C.R.; Otero, J.; Cabanillas, A.; Segovia, J.J. Low-grade coal and biomass co-combustion on fluidized bed: Exergy analysis. Energy 2006, 31, 330-344. [CrossRef]

85. De, S.; Assadi, M. Impact of cofiring biomass with coal in power plants-A techno-economic assessment. Biomass Bioenergy 2009, 33, 283-293. [CrossRef]

86. Wang, M.; Lawal, A.; Stephenson, P.; Sidders, J.; Ramshaw, C. Post-combustion $\mathrm{CO}_{2}$ capture with chemical absorption: A state-of-the-art review. Chem. Eng. Res. Des. 2011, 89, 1609-1624. [CrossRef]

87. Kaygusuz, K.; Türker, M.F. Biomass energy potential in Turkey. Renew. Energy 2002, 26, 661-678. [CrossRef]

88. Zeng, X.; Ma, Y.; Ma, L. Utilization of straw in biomass energy in China. Renew. Sustain. Energy Rev. 2007, 11, 976-987. [CrossRef]

89. Li, C.; Liu, D.; Ramaswamy, S.; Yan, J. Biomass energy and products: Advanced technologies and applications. Appl. Energy 2015, 157, 489-490. [CrossRef]

90. Wang, J.-J.; Yang, K.; Xu, Z.-L.; Fu, C. Energy and exergy analyses of an integrated CCHP system with biomass air gasification. Appl. Energy 2015, 142, 317-327. [CrossRef]

91. Gungor, A. Simulation of co-firing coal and biomass in circulating fluidized beds. Energy Convers. Manag. 2013, 65, 574-579. [CrossRef]

92. Tsatsaronis, G.; Morosuk, T.; Koch, D.; Sorgenfrei, M. Understanding the thermodynamic inefficiencies in combustion processes. Energy 2013, 62, 3-11. [CrossRef]

(C) 2017 by the authors; licensee MDPI, Basel, Switzerland. This article is an open access article distributed under the terms and conditions of the Creative Commons Attribution (CC BY) license (http:/ / creativecommons.org/licenses/by/4.0/). 